\title{
Resolving GABA /Benzodiazepine Receptors: Cellular and Subcellular Localization in the CNS with Monoclonal Antibodies
}

\author{
J. G. Richards, P. Schoch, P. Häring, B. Takacs, and H. Möhler \\ Pharmaceutical and Central Research Departments, F. Hoffmann-La Roche \& Co., Ltd., CH-4002 Basel, Switzerland
}

\begin{abstract}
Monoclonal antibodies, raised against a purified GABA $_{A}$ / benzodiazepine receptor complex from bovine cerebral cortex, have been used to visualize the cellular and subcellular distribution of receptorlike immunoreactivity in the rat CNS, cat spinal cord, and bovine and postmortem human brain.
\end{abstract} Two different antibodies have been used for these studies; bd-17 recognizes the $\beta$-subunit $(M, 55 \mathrm{kDa})$ in all the species tested, whereas bd-24 recognizes the $\alpha$-subunit ( $M, 50 \mathrm{kDa}$ ) of bovine and human but not rat and cat tissues. In bovine and human brain, both antibodies produced very similar staining patterns, indicating a homogeneous receptor composition, at least in the brain areas investigated. The general distribution and density of receptor antigenic sites in all tissues studied were very similar to that of benzodiazepine binding sites radiolabeled with ${ }^{3} \mathrm{H}$-Ro $15-1788$ and of glutamate decarboxylase (GAD)-stained nerve terminals. The results demonstrate a very high receptor density (around neuronal cell bodies and processes or less discretely distributed) in the rat olfactory bulbs, cerebral cortex, ventral pallidum, islands of Calleja, globus pallidus, hippocampus, dentate gyrus, substantia nigra, geniculate nuclei, inferior colliculus, cerebellum, reticular formation, spinal cord, and retina. In contrast, no receptors could be detected in white matter, pineal, pituitary, adrenals, and superior cervical ganglia. Only among the cerebellar layers did we observe a conspicuous difference between the staining intensity and the radiolabeling. In bovine and postmortem human brain, e.g., hippocampus, dentate gyrus, cerebral cortex, and substantia nigra, the same close correlation between the immunohistochemical and radiohistochemical findings was observed. At the electron microscopic level, the immune reaction product in the rat substantia nigra and globus pallidus, for example, was localized to pre- and postsynaptic membranes of axodendritic and axosomatic synapses. Whether the presynaptic labeling represents GABA autoreceptors is discussed.

In the near future, the monoclonal antibodies will be used in double-labeling experiments with GAD to identify those GABAergic projections that are modulated by benzodiazepine minor tranquillizers. Furthermore, they could also be

\footnotetext{
Received Aug. 29, 1986; revised Dec. 17, 1986; accepted Dec. 23, 1986.

We wish to thank Zaiga Bleuel and Roland Krauer for excellent technical assistance, Martine Wdonwicki for typing, and Professor Willy Hacfely for his critical assessment of the manuscript.

Correspondence should be addressed to Dr. J. G. Richards, Pharmaceutical Research Department, Bldg. 69, Rm. 234, F. Hoffmann-La Roche \& Co., Ltd., CH-4002 Basel, Switzerland.

Copyright (C) 1987 Society for Neuroscience $0270-6474 / 87 / 061866-21 \$ 02.00 / 0$
}

used, in studies of postmortem human brain, to diagnose receptor dysfunction possibly associated with CNS disorders such as epilepsy.

GABA, the major inhibitory neurotransmitter in many parts of the CNS (Roberts, 1986), acts through a so-called GABA receptor to gate a coupled chloride channel. Ligands of the benzodiazepine receptor (Möhler and Okada, 1977; Squires and Braestrup, 1977) allosterically modulate the function of this receptor/channel complex. A unique feature of this modulatory component, which forms an integral part of the $\mathrm{GABA}_{\mathrm{A}}$ receptor complex, is its ability to mediate opposite pharmacological effects, by reducing or increasing GABAergic transmission, depending on the type of receptor ligand. The benzodiazepine minor tranquillizers trigger off their therapeutic effects by enhancing $\mathrm{GABA}_{\mathrm{A}}$ receptor function (see Haefely et al., 1985).

Previous attempts to map the distribution and density of benzodiazepine receptors in the CNS have used quantitative autoradiography with image analysis to evaluate in vitro or in vivo binding of radioligands in tissue sections (see Kuhar et al., 1986). The limitations of such an approach (inherent poor resolution due to radiation scatter, ligand specificity, and possible ligand diffusion away from the binding site) are not encountered when using an immunohistochemical method. Monoclonal antibodies were recently raised against a purified $\mathrm{GABA}_{\mathrm{A}} /$ benzodiazepine receptor from bovine cerebral cortex. The antibodies reacted selectively with either the $\alpha$ - or the $\beta$-subunit of the receptor complex (Häring et al., 1985; Schoch et al., 1985). An immunohistochemical study was performed to visualize GA$\mathrm{BA}_{\mathrm{A}}$ /benzodiazepine receptor antigenic sites in rat CNS, cat spinal cord, and bovine and postmortem human brain with a resolution hitherto not achieved by the radiohistochemical approach (Richards et al., 1986b). A detailed cellular and subcellular localization of these receptors should help to identify the sites of GABAergic innervation in the brain that are modulated by benzodiazepines. Furthermore, since the antibodies were subunit specific, information about the receptor composition in different brain areas and species can be deduced.

\section{Materials and Methods}

Tissue preparation. Male albino SPF rats (specific pathogen free, Füllinsdorf, weighing $120 \mathrm{gm}$ ), cat spinal cord, and bovine and postmortem $(3 \mathrm{hr})$ human brain were used. Rats were fixed by vascular perfusion ( $20 \mathrm{~min}$ ) with an ice-cold solution of $2 \%$ formaldehyde (generated from paraformaldehyde powder) and $0.1 \%$ glutaraldehyde in PBS followed by immersion $(2 \mathrm{hr})$ with agitation of tissues in the same fixative. Cat spinal cord and bovine and human brain were fixed by immersion ( 3 hr).

For light microscopy, all tissues were stored in ice-cold $20 \%$ sucrose 
in PBS (overnight), then frozen on microtome chucks in dry ice. Tenmicron cryostat sections were thaw-mounted onto acid-cleaned and subbed slides and then stored at $4^{\circ} \mathrm{C}$ until used.

For electron microscopy, tissues were stored in ice-cold $7 \%$ sucrose in PBS (overnight), then $50 \mu \mathrm{m}$ Vibratome sections were prepared.

Postmortem human brain was kindly provided by Prof. W. Wegmann, Institute of Pathology, Kantonsspital, Liestal.

Antibody preparation. Monoclonal antibodies were produced after immunizing mice with a highly purified $\mathrm{GABA}_{\mathrm{A}}$ /benzodiazepine receptor preparation from bovine cerebral cortex. The preparation and immunobiological characteristics of these antibodies have been recently described (Schoch et al., 1984, 1985; Häring et al., 1985; Möhler et al., 1986). Out of 16 different monoclonal antibodies distinguishing 4 different epitopes in the receptor complex, only 2 have been used for the present study. Antibody bd-17 is specific for the $\beta$-subunit $\left(M_{r} 55 \mathrm{kDa}\right)$ and recognizes the human, bovine, cat, and rat receptor, whereas bd24 is specific for the $\alpha$-subunit $(M, 50 \mathrm{kDa})$. It only recognizes the human and bovine receptor.

For comparison, some adjacent section surfaces were stained with an antibody to glutamate decarboxylase (GAD) (kindly provided by Dr. J. Y. Wu, Pennsylvania State University, Department of Physiology). Other serial sections were radiolabeled with ${ }^{3} \mathrm{H}-\mathrm{Ro} 15-1788$ in vitro as previously described (Richards and Möhler, 1984). A further serial section was stained with cresyl violet for histological identification of the various tissues.

Immunohistochemical procedure. (1) Cryostat sections were incubated, according to the indirect peroxidase-antiperoxidase (PAP) technique (Sternberger, 1979), in sequence with the following reagents (Nordic Immunology) in PBS $+0.2 \%$ Triton at $20^{\circ} \mathrm{C}: 20 \%$ normal swine serum (30 min; Nordic), $50 \%$ hybridoma supernatant bd-17 or bd-24 (5-10 $\mu \mathrm{g} / \mathrm{ml}$ ) (overnight at $4^{\circ} \mathrm{C}+2 \mathrm{hr}$ at $20^{\circ} \mathrm{C}$ ), $3.3 \%$ swine anti-mouse antiserum ( $30 \mathrm{~min}$; Nordic) with $3 \times 10 \mathrm{~min}$ PBS-Triton rinses between each incubation. This was then followed by incubation with $3.3 \%$ mouse PAP (30 min; Nordic), PBS-Triton ( $5 \mathrm{~min})$, Tris buffer $(+\mathrm{NaCl})$-Triton $(2 \times 5 \mathrm{~min})$, diaminobenzidine/Tris buffer $(10.5 \mathrm{mg}$ in $15 \mathrm{ml})$ with $\mathrm{H}_{2} \mathrm{O}_{2}(15 \mathrm{~min})$, distilled water rinse $(5 \mathrm{~min})$, dehydration, clearing, and mounting in DePex. Some sections were subsequently treated with $0.5 \%$ aqueous $\mathrm{OsO}_{4}$ for $20 \mathrm{sec}$ prior to dehydration. (2) Vibratome sections were incubated as above, but before dehydration and embedding in Epon, they were postfixed with $2 \% \mathrm{OsO}_{4}$ in $0.1 \mathrm{~m}$ sodium cacodylate buffer at $\mathrm{pH} 7.4\left(60 \mathrm{~min}\right.$ at $4^{\circ} \mathrm{C}$ with agitation). Ultrathin sections were prepared of tissue proximal to the surface of the Vibratome slice.

The GAD antibody was diluted 1:400. Adsorption controls were carried out with primary antibodies preincubated with a purified receptor preparation (Schoch et al., 1984).

Microscopy. Immunoreacted cryostat sections were used as negatives for macroscopic images (resembling dark-field optics). They were also viewed and photographed with Zeiss bright-field, dark-field and interference contrast (Nomarski) optics. Counterstained or unstained ultrathin sections were examined with a Philips EM 300 electron microscope.

The rat brain stereotaxic atlas of Paxinos and Watson (1982) was used for reference. In addition, the following review articles were consulted: Shepherd, 1972; Macrides and Davis, 1983 (olfactory bulb); Emson and Hunt, 1981; Parnavelas and McDonald, 1983; Schulman, 1983 (cerebral cortex); Lorente de Nó, 1934; Storm-Mathisen, 1978; Walaas, 1983; Schwerdtfeger, 1984; Teyler and Discenna, 1984 (hippocampus); Jones, 1983 (thalamus); Silverman and Pickard, 1983 (hypothalamus); Shiosaka et al., 1983 (amygdala); Palay and Chan-Palay, 1974 (cerebellum); Hunt, 1983; Molander et al., 1984 (spinal cord); and Brecha, 1983 (retina).

\section{Results}

In agreement with previous immunobiochemical findings (Häring et al., 1985; Schoch et al., 1985), the 2 antibodies tested were found to be species specific. Thus, whereas bd-17 (a $\beta$-subunit spccific antibody) was positive in the 4 species investigated, bd-24 (an $\alpha$-subunit specific antibody) was negative in the rat and cat. However, in those species for which both bd17 and bd- 24 were immunoreactive, bovine and human brain, the staining patterns of the 2 antibodies were very similar, which is consistent with the concept of a hetero-oligomeric composition of the receptor containing $\alpha$-and $\beta$-subunits. Among the different brain regions investigated, no indication was found for a receptor heterogeneity at the level of the $\alpha$ - and $\beta$-subunit composition.

\section{Macroscopic pattern of immunoreactivity}

We observed a marked heterogeneity in the pattern of immunohistochemical staining with the monoclonal antibodies in all tissues investigated. Receptor immunoreactivity was concentrated in those regions of the CNS with a known GABAergic innervation (see Barber and Saito, 1976; Fagg and Foster, 1983; Ottersen and Storm-Mathisen, 1984; Wamsley and Palacios, 1984; Mugnaini and Oertel, 1985; Somogyi et al., 1985) and for which specific ligands ( ${ }^{3} \mathrm{H}$-Ro $15-1788$, -muscimol, -bicuculline and ${ }^{35} \mathrm{~S}$-TBPS) of the $\mathrm{GABA}_{\mathrm{A}} /$ benzodiazepine receptor $/ \mathrm{Cl}^{-}$channel complex are known to have a high affinity (see Young and Kuhar, 1979b, 1980; Bowery et al., 1984; Richards and Möhler, 1984, 1985; Richards et al., 1984, 1986c; Wamsley et al., 1985). The general distribution of immunoreactive sites in the rat CNS, cat spinal cord, and bovine and postmortem human brain (Fig. 1) compared favorably with that of benzodiazepine binding sites labeled in vitro with ${ }^{3} \mathrm{H}-\mathrm{Ro}$ 15-1788 published previously (Richards and Möhler, 1984; Schoch et al., 1985).

\section{Immunohistochemical findings}

The immune reaction in the CNS was observed as a discrete staining of cell processes (presumably dendrites) and cell body profiles (presumably neurons) or a more diffuse granular staining. Immunoreactive cell processes were found in the internal plexiform and granular layers of the main and accessory olfactory bulbs, in the islands of Calleja, ventral pallidum, globus pallidus, hippocampus, dentate gyrus, substantia nigra reticular, cerebellar molecular laycr, reticular formation, spinal cord, and retina. In several brain regions there was a more diffuse but granular immune reaction, e.g., in cerebral cortex, inferior colliculus, spinal cord (layers II, III; -substantia gelatinosa). In a few regions staining occurred around what appeared to be neuronal cell bodies, e.g., in the mitral cell, internal plexiform and granular layers of the olfactory bulb, in the anterior olfactory nucleus, islands of Calleja, pallidum, anterior commissure, hippocampus, dentate gyrus, substantia nigra reticular, cerebellum, reticular formation, spinal cord, and retina. As far as could be judged, immunoreactivity was rarely found within neurons and never in or around glial cells.

The following account describes (in a rostrocaudal sequence) representative examples of the immunohistochemical findings for the CNS of the 4 species investigated.

In the main and accessory olfactory bulbs, the external plexiform layer was the most intensely stained; there, as in the glomerular layer, the reaction was so intense that distinct fibers could hardly be resolved (Figs. $1 A, 2 A$ ). In the mitral cell, internal plexiform, and granular layers, numerous cell profiles and processes were discretely stained (Fig. $2 B$ ). Isolated immunoreactive cell profiles and their processes were present in the dorsal anterior olfactory nucleus. The olfactory nerve layer was devoid of an immune reaction.

Throughout the cerebral cortex (Fig. $1 A$ ), the immune reaction was intense but diffuse. Discretely stained cells or cell processes were rarely observed. The finely granular immune reaction was notably weakest in layers I and V. The corpus callosum was not stained except for isolated cells and processes adjacent to layer VI. 

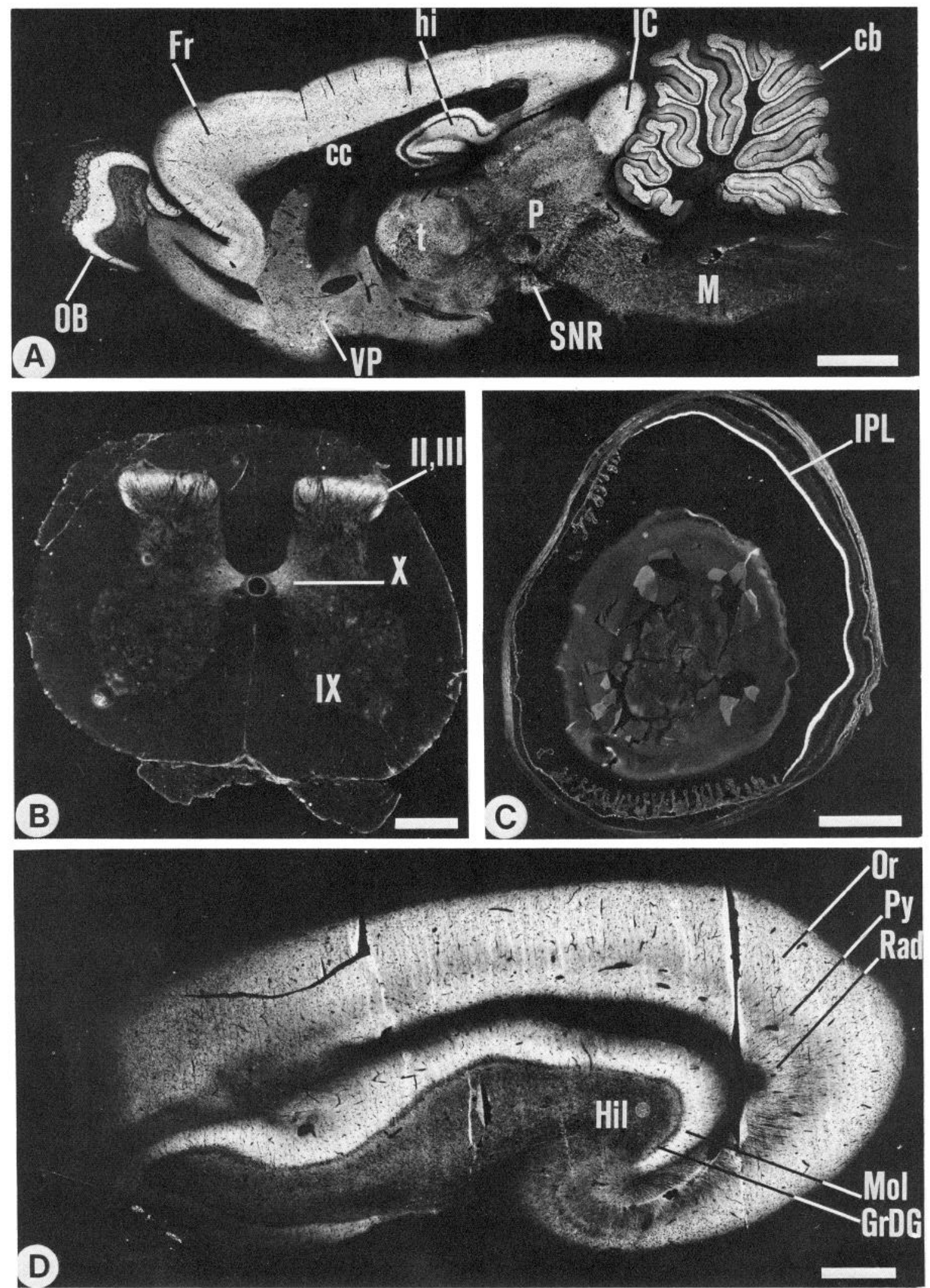

Figure 1. Macroscopic images of the distribution of immunoreactivity (white areas) in rat brain (parasagittal section), cat spinal cord (lumbar frontal section), rat retina (vertical section), and human postmortem hippocampus and dentate gyrus (coronal section) using bd-17, a $\beta$-subunitspecific monoclonal antibody $(\mathrm{mAb})$. Bars, $2 \mathrm{~mm}(A), 1 \mathrm{~mm}(B-D)$. See Appendix for abbreviations used in this and all other figures. 
Table 1. Summary of the properties of $m A b$ directed against $\mathrm{GABA}_{\mathrm{A}} /$ benzodiazepine receptors $^{a}$

\begin{tabular}{|c|c|c|c|c|c|}
\hline Property & \multicolumn{5}{|c|}{ Characterization } \\
\hline Antigen & \multicolumn{5}{|c|}{$\begin{array}{l}\text { Solubilized receptor preparation from bovine cerebral cortex, purified } \\
\text { on an affinity column }\end{array}$} \\
\hline Screening assay & \multicolumn{5}{|c|}{ Solid-phase antibody binding assay with purified receptor as substrate } \\
\hline Specificity & \multirow{3}{*}{\multicolumn{5}{|c|}{$\begin{array}{l}\text { Immunoprecipitation of high- and low-affinity GABA binding sites, } \\
\text { benzodiazepine-, and TBPS-binding sites from a crude brain } \\
\text { solubilisate, and purified receptor preparation } \\
\text { No precipitiation of noradrenergic and muscarinic binding sites } \\
\text { No interaction on immunoblots of peripheral tissues }\end{array}$}} \\
\hline & & & & & \\
\hline & & & & & \\
\hline \multirow[t]{4}{*}{$\begin{array}{l}\text { Subunit and species } \\
\text { specificity }\end{array}$} & \multicolumn{5}{|c|}{$\begin{array}{l}\text { Immunoprecipitation and immunoblot experiments with purified } \\
\text { receptor preparations }\end{array}$} \\
\hline & Group & $\mathrm{mAb}$ & Subunit & $\begin{array}{l}\text { Bovine/ } \\
\text { human }\end{array}$ & Rat/cat \\
\hline & I & bd-17 & $\beta(55 \mathrm{kDa})$ & + & + \\
\hline & II & bd-24 & $\alpha(50 \mathrm{kDa})$ & + & - \\
\hline
\end{tabular}

${ }^{a}$ See Häring et al., 1985.

In pallidal regions (Figs. 3, 4A), the islands of Calleja, ventral pallidum (substantia innominata) and globus pallidus were among the most discretely stained brain regions examined. In all these regions, isolated cell bodies and numerous processes were strongly immunoreactive on a virtually unstained background. In contrast, the caudate putamen (Fig. $4 A$ ) contained a very fine, diffuse immune reaction. Although the anterior commissure and internal capsule fibers were unstained, we frequently observed immunoreactive isolated cells and their varicose processes in the white matter (Fig. $4 B$ ).

In the hippocampus and dentate gyrus (Fig. 5), whereas the pyramidal and granule cell layers of these regions were only rarely stained, the oriens, radiatum, and lacunosum moleculare layers of the hippocampus and particularly the dorsal blade of the molecular layer in the dentate gyrus were characterized by an intense, finely granular immune reaction. Individual cell profiles and fibers were frequently stained in the outermost oriens layer and occasionally in the pyramidal cell layers; in the hilus, processes of immunoreactive cell profiles were observed projecting through the granule cell layer into the molecular layer of the dentate gyrus (Fig. $5 C$ ). The CA3 region of Ammon's horn was distinctly less stained than the CA1 region (Fig. $5 B$ ). The lower blade of the dentate gyrus molecular layer was invariably poorly stained. No staining was observed in the fimbria, alveolus, and subiculum.

The thalamus, particularly the rostral laterodorsal and lateroventral regions and the zona incerta (but not the epithalamic habenular nuclei), contained a moderate to intense finely granular immune reaction.

Most hypothalamic nuclei were finely stained throughout: Immunoreactive isolated cell profiles could be observed. The median eminence was generally devoid of an immune reaction.

Among the amygdaloid nuclei, the lateral amygdaloid nucleus was most intensely stained (finely granular immune reaction).

The substantia nigra, reticular area (Fig. $6 A$ ) contained a high density of intensely stained fibers and isolated cell profiles. The cerebral peduncle was not stained. In postmortem human brain (Fig. 6B), individual fibers and cells on an unstained background could be observed. Since highly stained pigmented cells were present even when the primary antibody was omitted, their staining was considered to be nonspecific.
The superficial layers of the superior and particularly throughout the inferior colliculi contained a finely granular immune reaction. The dorsal and median raphé nuclei contained discretely stained fibers and a finely granular immune reaction. The nucleus of the dorsolateral lemniscus was intensely stained, but no individual fibers could be resolved.

In the cerebellum (Fig. 7), whereas the granular layer (between and around the granule cells proper) was intensely immunoreactive, the Purkinje cell layer and white matter were unstained. In the molecular layer, however, discretely stained small cell profiles and fibers (occasionally appearing parallel, depending upon the plane of section through each lobule) were prominent features. The stained fibers appeared to extend to the surface of the lobules. Deep cerebellar nuclei (e.g., Deiters' nucleus) contained discretely stained fibers and cell profiles.

In the medulla, receptor antigenic sites were present on numerous cells and processes in the reticular formation (parvocellular, gigantocellular, oral, and caudal pontine nuclei) (Fig. $8 A)$.

The most prominent features in the spinal cord (Figs. $1 B, 8 B$ ) were the intense finely granular immune reaction in layers IIIV, as well as the numerous discretely stained fibers and isolated cells in layers VI-VIII and X. The ventral horn (particularly layer IX) and the funiculi were generally devoid of any staining except for isolated fibers that projected through layer IX and into the ventral funiculi. There was no visible staining around $\gamma$-motor neurons.

In the retina (Figs. $1 C, 9$ ), isolated, discretely stained cells occurred in the inner nuclear layer; they appeared to send single projections to the adjacent inner plexiform layer, where they seemed to branch and form a dense arborization with 3 distinct bands of a highly granular nature.

Among other tissues and organs investigated, the pineal, pituitary, adrenals, kidney, and superior cervical ganglia were devoid of a visible immune reaction light microscopically.

\section{Immunocytochemical findings}

The subcellular distribution of immune reactivity in the rat substantia nigra (reticular zone) and globus pallidus was studied by electron microscopy. A distinct, highly electron-dense reaction product was observed exclusively in axodendritic and the oc- 

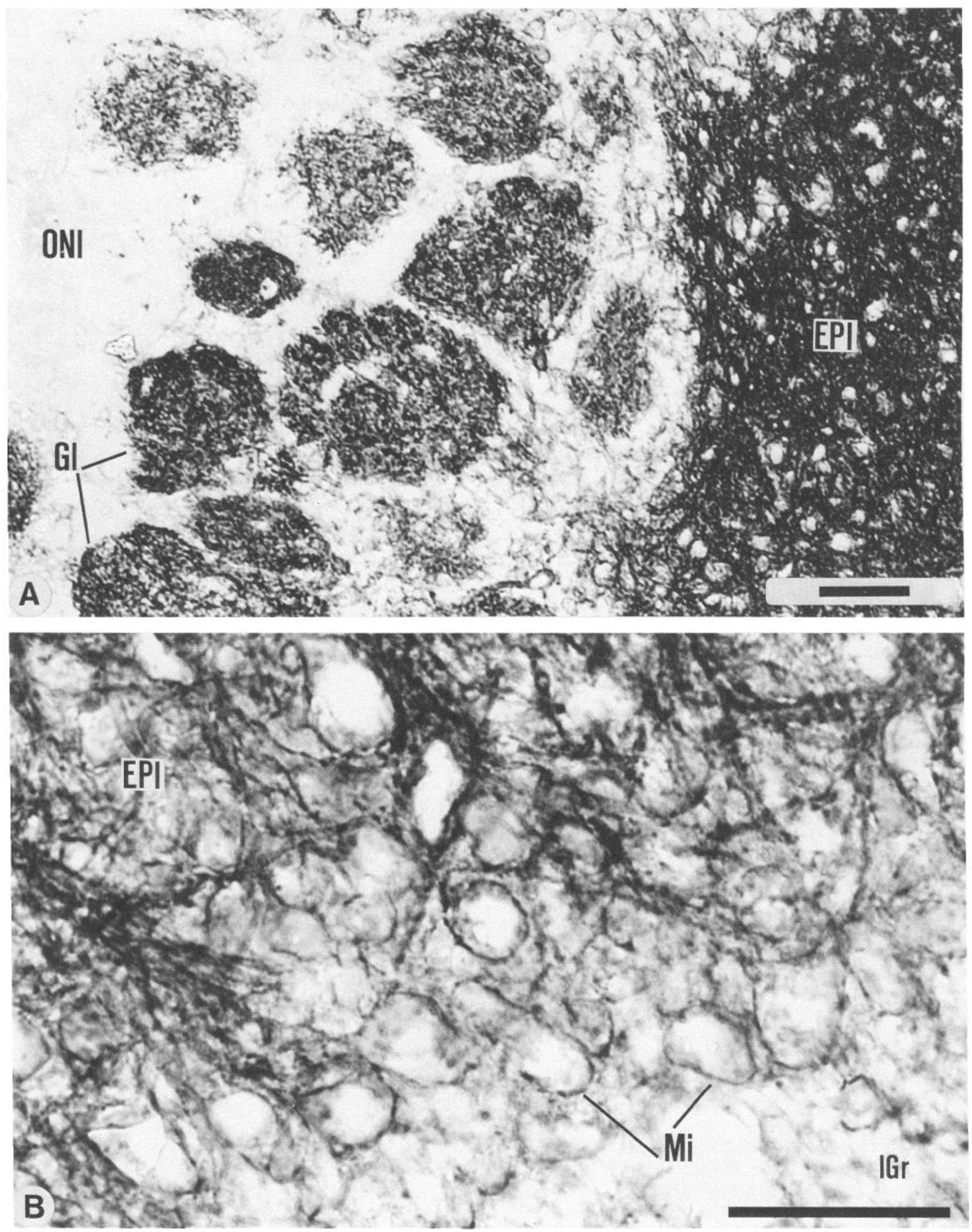

Figure 2. Microscopic distribution of immunoreactivity (dark areas) in rat olfactory bulb using mAb bd-17 (bright-field optics). Note the intense staining of the external plexiform and glomerular layers but the absence of stain in the olfactory nerve layer $(A)$. At higher magnification $(B)$, mitral cell profiles also appear highly stained. Bars, $50 \mu \mathrm{m}$. 


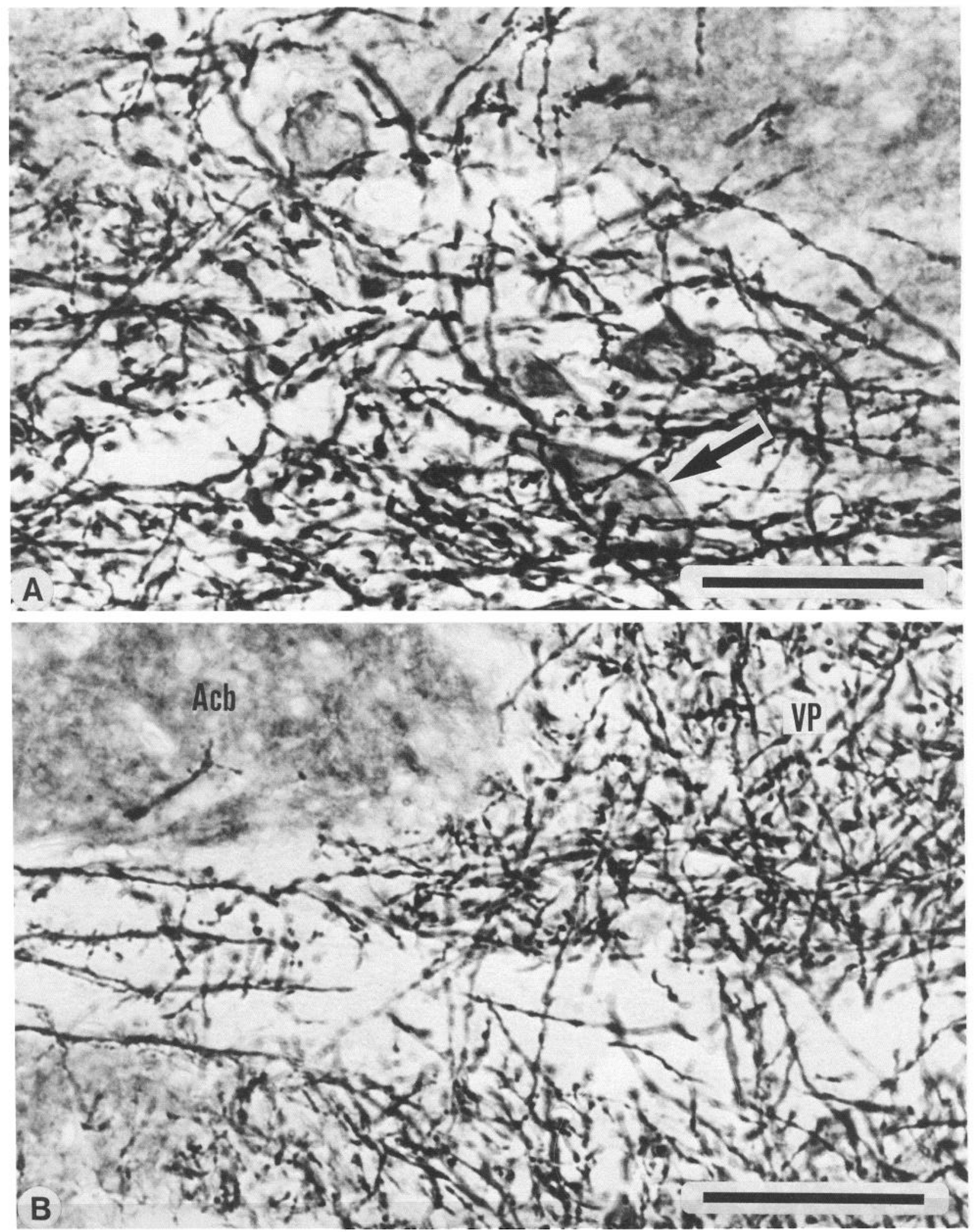

Figure 3. Microscopic distribution of immunoreactivity in an island of Calleja and ventral pallidum, respectively, of a rat using mAb bd-17 (bright-field optics). Note the numerous immunoreactive fibers in both regions. A cell profile (arrow) in $A$ is also clearly stained. In the nucleus accumbens rostral to the pallidum $(B)$, the immune reaction is, in contrast, extremely fine. Bars, $50 \mu \mathrm{m}$. 


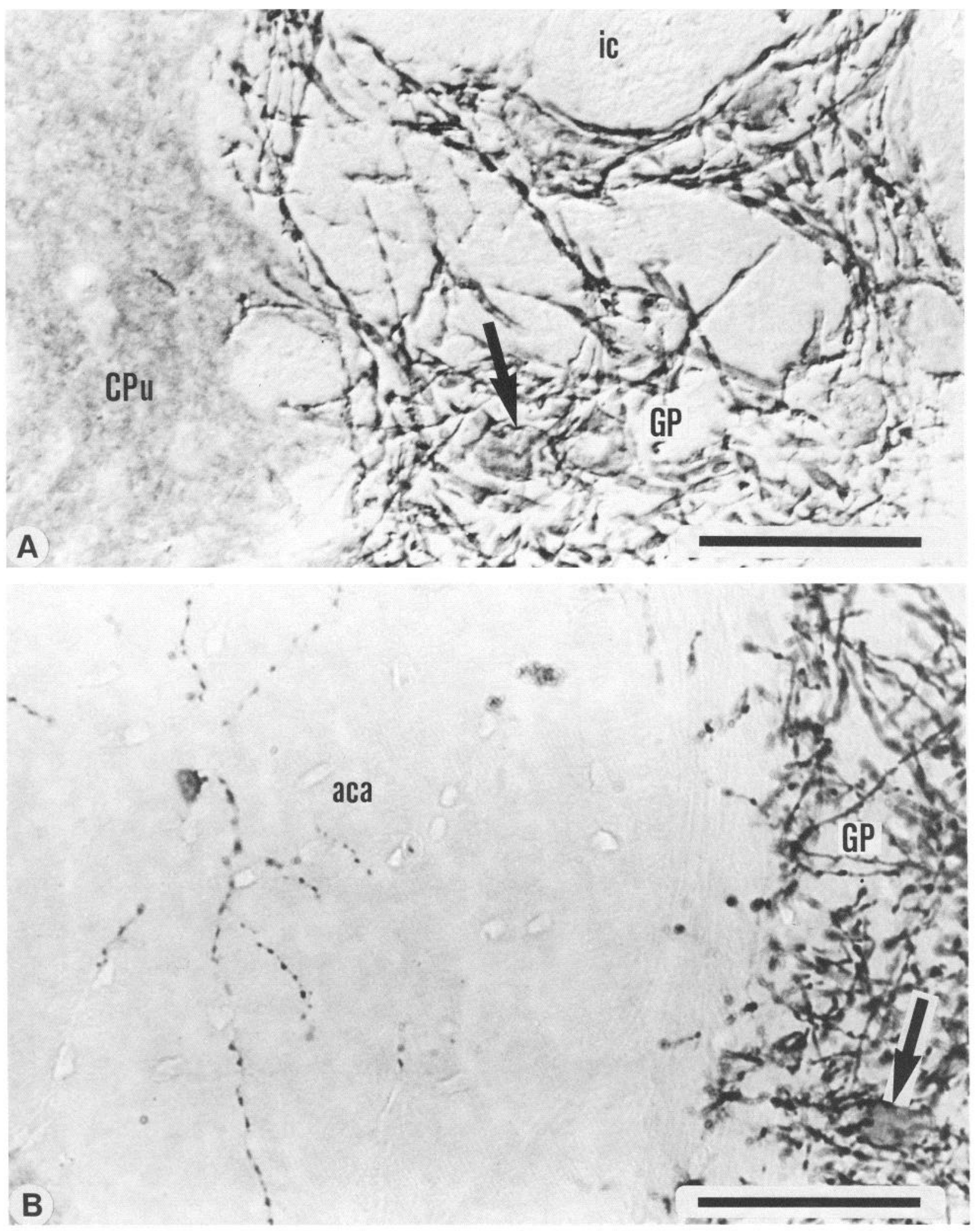

Figure 4. Microscopic distribution of immunoreactivity in rat globus pallidus, caudate putamen, and anterior commissure using mAb bd-17 (Normarski and bright-field optics, respectively). Note the intensely stained fibers and occasional cells (arrows) in the globus pallidus compared to the finely stained caudate putamen. Internal capsule fibers are free of stain. The anterior commissure $(B)$ contains a discretely immunoreactive cell and several varicose processes. Bars, $50 \mu \mathrm{m}$. 

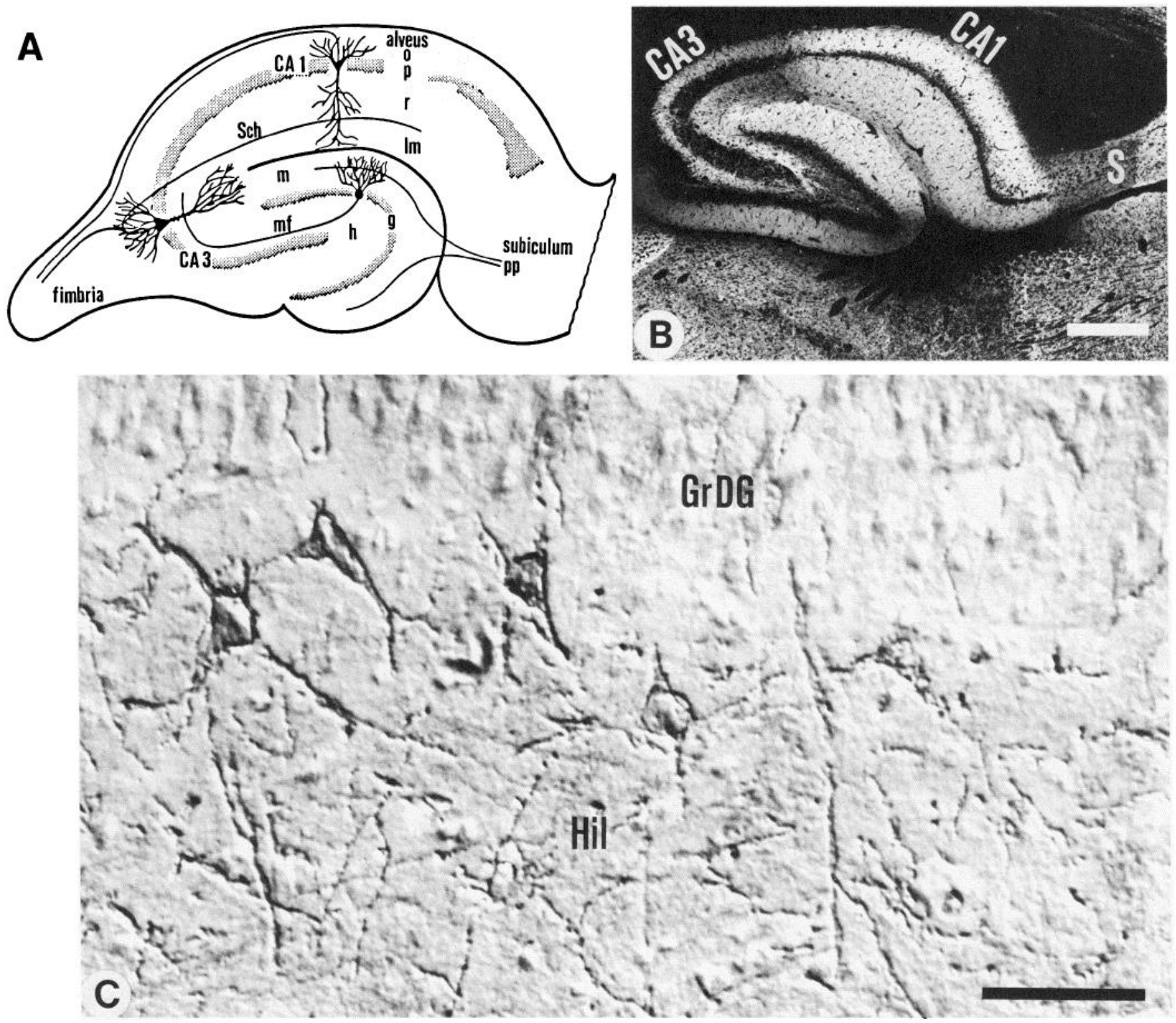

Figure 5. A, Schematic illustration of the principal structural features of the hippocampal formation. $B$ and $C$, Macroscopic and microscopic distribution of immunoreactivity in rat hippocampal formation (white areas) and bovine dentate gyrus (dark areas), respectively, using bd-17. Note the intense staining in the various layers (CA1 > CA3) and the virtual absence of stain in the pyramidal and granule cell layers, fimbria and alveus. In the dentate gyrus $(C$, Normarski optics), several immunoreactive cell profiles and their processes are present in the hilus just below the granule cell layer. Bars, $2 \mathrm{~mm}(B), 50 \mu \mathrm{m}(C)$.

casional axosomatic synaptic contacts in lightly counterstained (Fig. 10) or unstained sections. The immune reaction was present not only on the postsynaptic membrane but also presynaptically. Most of the immunoreactive axodendritic synapses were on medium to large dendrites and only few were present on small dendritic spines.

\section{Discussion}

Receptor mapping with an anatomical resolution was revolutionized by the introduction, some 7 years ago, of a radiohistochemical technique for in vitro binding studies of neurotransmitters and drugs (Young and Kuhar, 1979a; Kuhar et al., 1986). While this is clearly still the method of choice for qualitative and quantitative anatomical studies of the pharmacology of receptors in vitro and, more recently, also in vivo (Goeders and Kuhar, 1985; Ciliax et al., 1987; Richards et al., unpublished observations), an immunohistochemical approach would have a number of advantages; in particular, the problems of the specificity of ligand binding, ligand diffusion, and radiation scatter encountered with the radiohistochemical technique are overcome. Receptor antigenic sites for glycine and ACh (nicotinic) receptors have been visualized by nondiffusible markers such as peroxidase-coupled or colloidal gold-coupled secondary antibodies (Lentz and Chester, 1977; Nghiêm et al., 1983; Sealock et al., 1984; Triller et al., 1985).

In the present study, monoclonal antibodies were used that had been raised against an isolated partially purified $\mathrm{GABA}_{\mathrm{A}}$ / benzodiazepine receptor from bovine cerebral cortex (Schoch et al., 1984, 1985; Häring et al., 1985). Out of the hybridoma cultures, we chose 2 secreting species- and subunit-specific antibodies (bd-17 and bd-24; isotype $\mathrm{IgGl}$ ), for extensive mapping of receptorlike immunoreactivity in rat $\mathrm{CNS}$, cat spinal cord, 


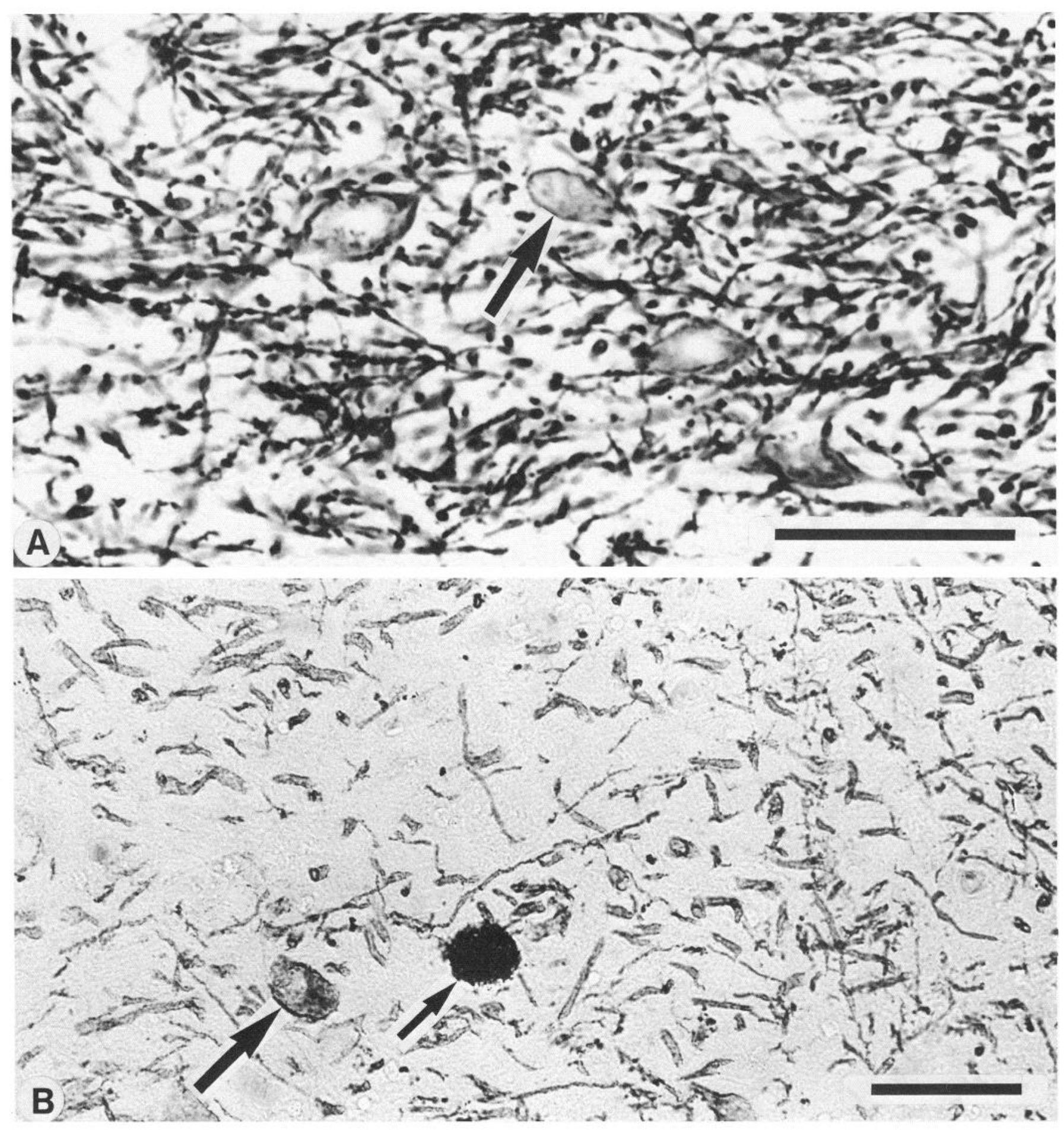

Figure 6. Microscopic images of immunoreactivity in the substantia nigra (reticular region) of rat $(A)$ and human postmortem brain $(B)$ using mAbs bd- 17 and bd-24 (bright-field optics). In both tissues, numerous stained fibers and the occasional cell profile (large arrows) are present. The highly stained pigment cells in the human tissue (smaller arrow) could also be observed when the primary antibody was omitted. Bars, $50 \mu \mathrm{m}$.

and bovine and postmortem human brain.

The regional pattern of immunohistochemical staining with the $\beta$-subunit specific antibody (bd-17) in the rat brain, spinal cord, and retina correlates well with the distribution of GABAergic nerve terminals in the CNS. Moreover, the identical distribution of receptor antigenic sites in bovine and postmortem human brain revealed by the $\alpha$ - and $\beta$-subunit specific antibodies (bd-24 and bd-17, respectively) indicates a structural homogeneity of the receptor in the different brain areas investigated. The cellular and subcellular resolution of the immune reaction, found exclusively in the CNS, reveals the cellular target for benzodiazepine minor tranquilizers with a detail hitherto not achieved. The findings are compatible with the localization of benzodiazepine receptors on, for example, primary and secondary mitral cell dendrites and their perikarya, pyramidal and granule cell dendrites, possibly basket cells and their dendrites, 

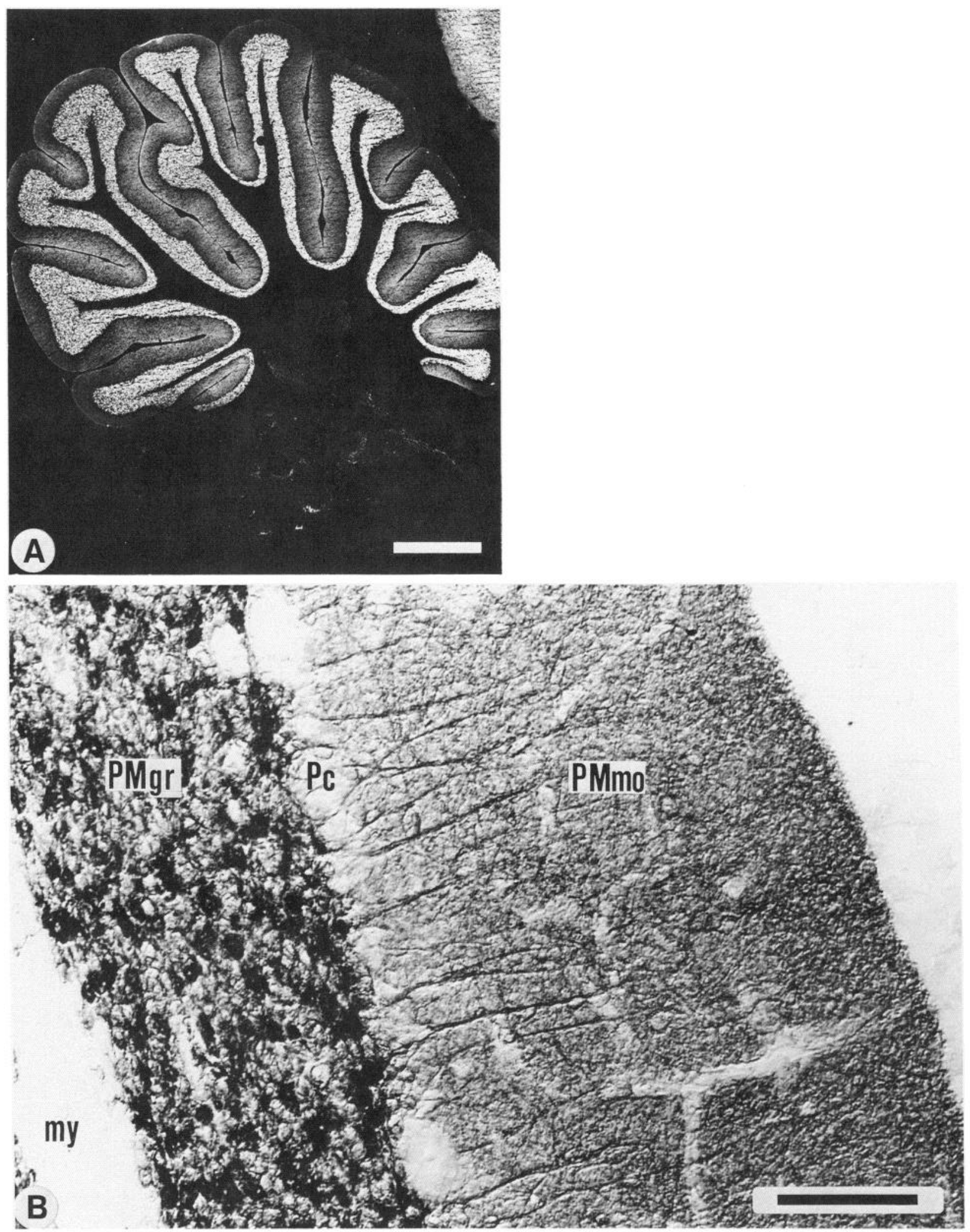

Figure 7. Macroscopic $(A)$ and microscopic $(B)$ images of the distribution of immunoreactivity (white and dark areas, respectively) in the rat cerebellum using $\mathrm{mAb}$ bd-17. In $B$ (Normarski optics), note the intense staining of the granular layer and the numerous stained fibers (and occasional cell profiles) in the molecular layer but the virtual absence of staining in the Purkinje cell layer and white matter. Bars, $1 \mathrm{~mm}(A), 50 \mu \mathrm{m}(B)$. 


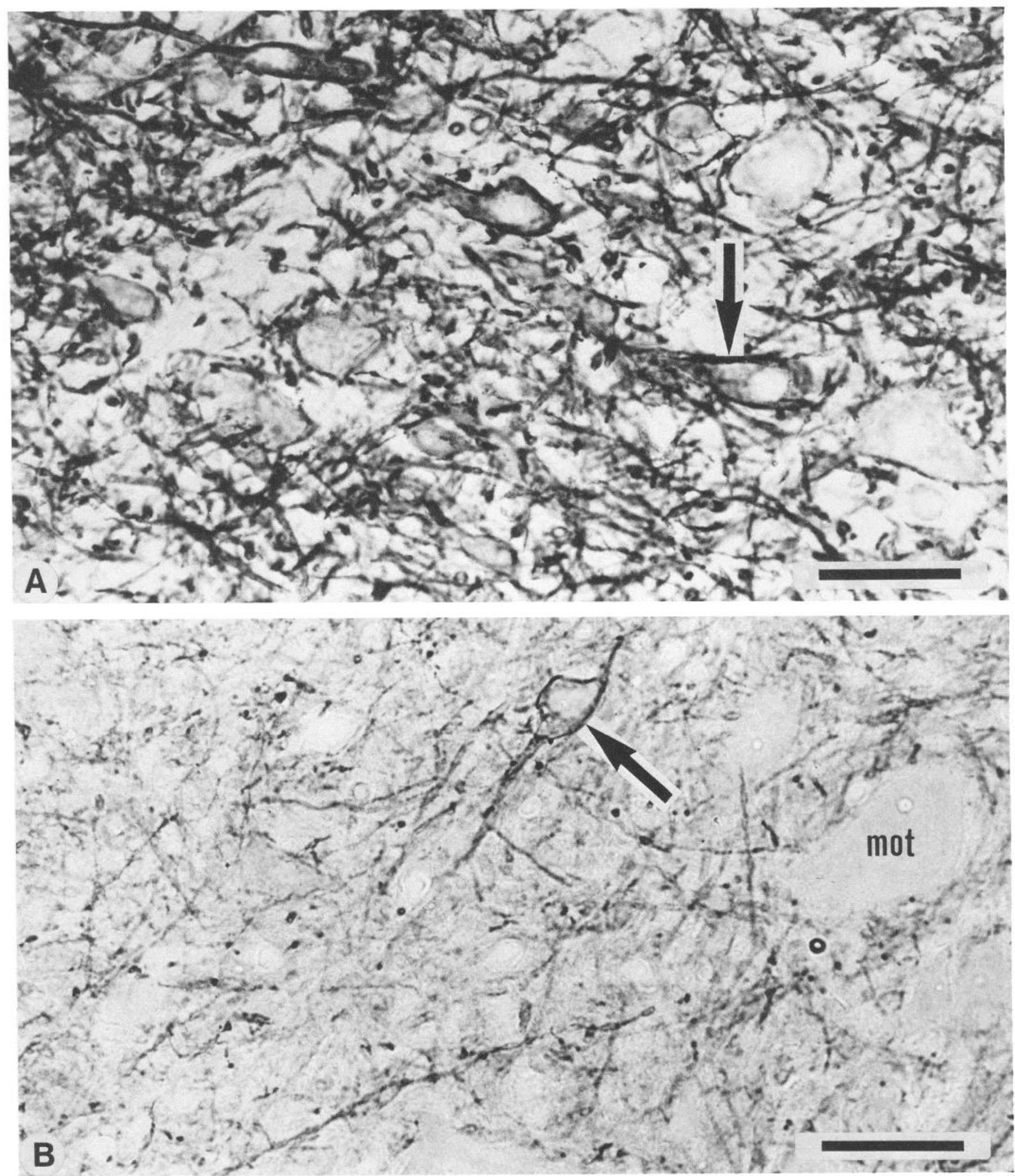

Figure 8. Microscopic images of the distribution of immunoreactivity in the $(A)$ rat reticular formation (caudal pontine nucleus) and $(B)$ rat cervical spinal cord (layer VIII) using mAb bd-17 (bright-field optics). Note the numerous immunoreactive fibers and several cell profiles in the reticular formation. In the spinal cord layer VIII, stained fibers and cell profiles (arrow) are present; motor neurons are devoid of stain. Bars, $50 \mu \mathrm{m}$. 


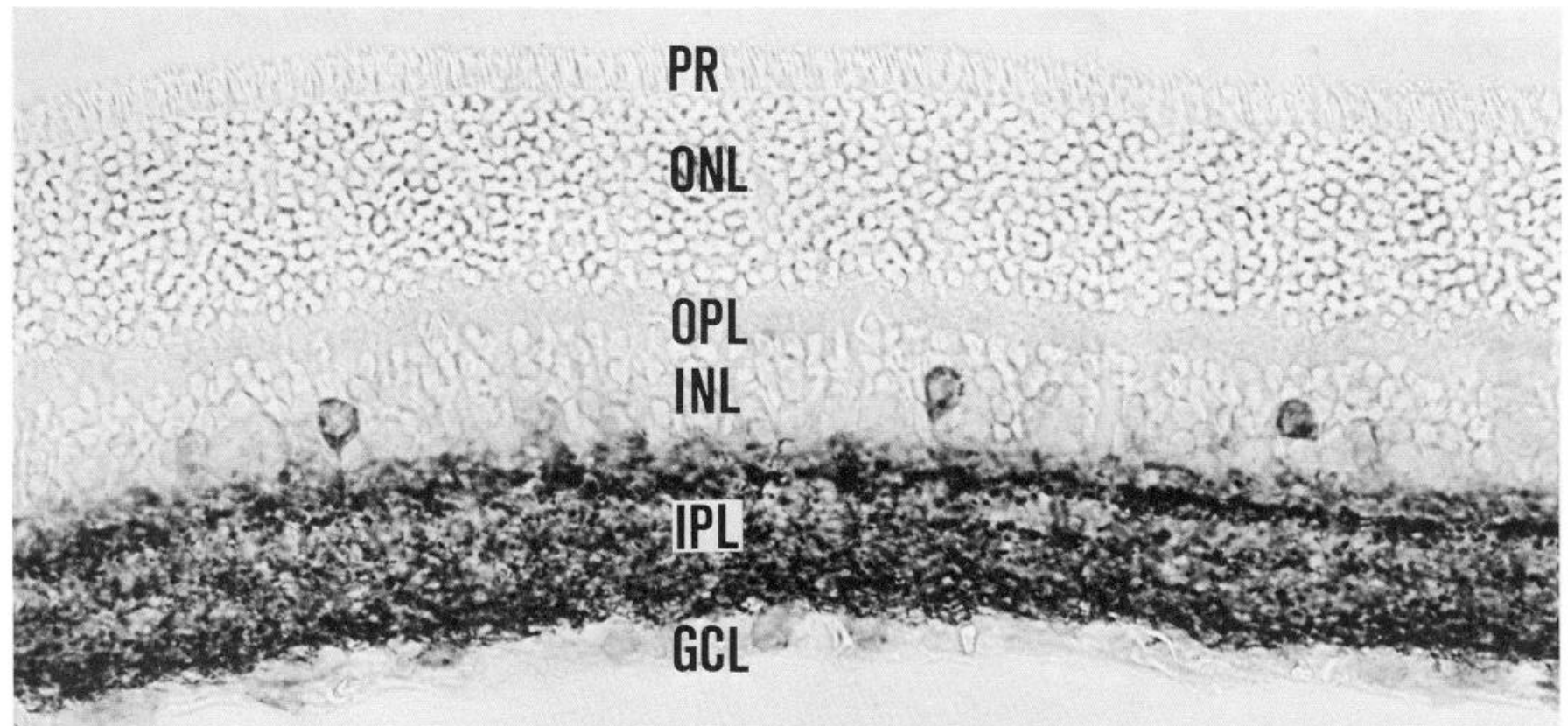

A
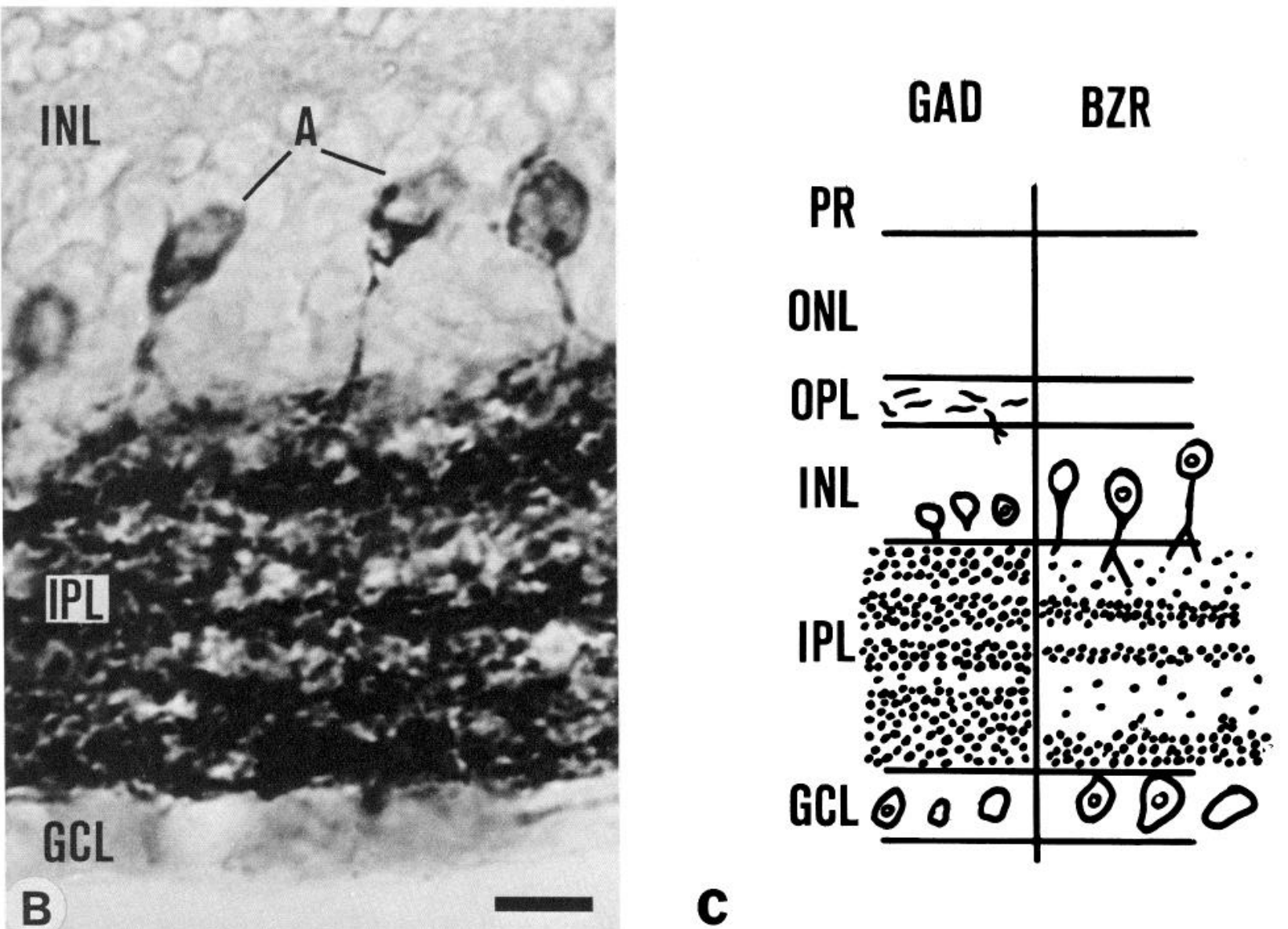

Figure 9. Microscopic images and schematic drawing of rat retina. $A$ and $B$, Distribution of immunoreactivity. Note the concentration of staining (frequently appearing as 3 distinct bands) in the internal plexiform layer and in a subpopulation of amacrine cells and ganglion cells in the inner nuclear and ganglion cell layers, respectively. $C$, Schematic drawing indicating the relative distribution of immunoreactivity to mAb bd-17 and $\mathrm{GAD}$, on the one hand, and of radiolabeled binding sites, on the other. Bars, $50 \mu \mathrm{m}(A), 10 \mu \mathrm{m}(B)$. 

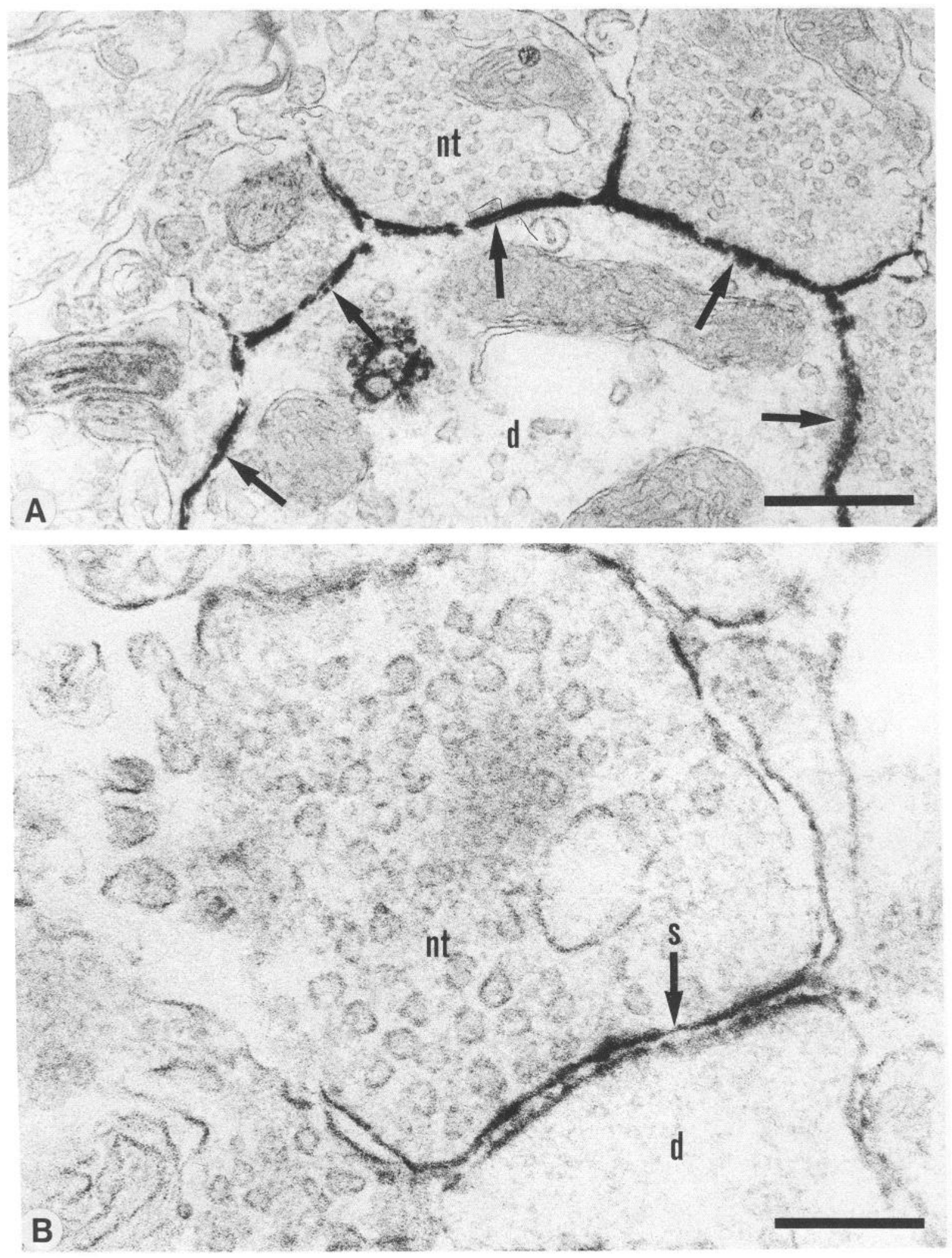

Figure 10. Electron microscopic distribution of immunoreactivity in rat substantia nigra using mAb bd-17. Note the presence of an electrondense immune reaction mainly in pre- and postsynaptic membranes of numerous axodendritic contacts (arrows). Lead citrate counterstaining. Bars, $0.5 \mu \mathrm{m}(A), 0.2 \mu \mathrm{m}(B)$. 
A9 dopaminergic cell dendrites, Purkinje cell dendrites, granule cells, amacrine cells, ganglion cells, and their processes.

Comparing the overall radio- and immunohistochemical patterns of benzodiazepine receptor distribution with that of GABAergic nerve terminals (Young and Kuhar, 1980; Richards and Möhler, 1984; Mugnaini and Oertel, 1985; Richards et al., 1986a), we conclude that, with a few exceptions, there is a good correspondence.

\section{Cellular localization of receptors}

In many regions of the CNS, receptor antigenic sites were found predominantly on neurons and dendrites; in some regions, their cellular localization could not be resolved light microscopically. In discussing the cellular localization of benzodiazepine receptors, we will describe those regions of the CNS whose GABAergic innervation and receptors, electrophysiology, or pharmacology are reasonably well documented and that have a moderate to high density of benzodiazepine receptors (Young and Kuhar, 1979b, 1980; Richards and Möhler, 1984; Wamsley and Palacios, 1984; Haefely and Polc, 1986; Richards et al., 1986c).

\section{Olfactory bulbs}

The main and accessory olfactory bulbs contained by far the highest density of receptor antigenic sites in the CNS. In correlation with the distribution of GABAergic nerve terminals was the intense staining of the glomerular and external plexiform layers. Benzodiazepine receptors are probably located on primary and secondary mitral cell dendrites which receive GABAergic nerve terminals from periglomerular and granule cells (Nicoll, 1971; Ribak et al., 1977; Halasz et al., 1979; Jaffé and Cuello, 1980, 1981; Jaffé et al., 1983; Mugnaini and Oertel, 1985). The nonimmunoreactive olfactory nerve layer contains neither GABAergic nerve terminals nor central-type benzodiazepine receptors but a high density of peripheral-type (glial?) receptors (Richards et al., 1982, 1986c). From the staining pattern, it appears that receptors are present also on mitral cells, some granule cells, and isolated cells and their processes in the lateral olfactory tract whose synaptic connections are as yet unknown. Ontogenetically, benzodiazepine receptors appear in the olfactory bulbs (more prominently in the accessory olfactory bulbs) by gestational day 16 (Schlumpf et al., 1983), which is precisely when receptors can be first detected immunohistochemically (unpublished observations).

GABAergic inhibitory mechanisms probably play a prominent role in the modulation of olfactory sensation in rodents (see Halasz and Shepherd, 1983). The effect of benzodiazepines in the bulbs has not been investigated, although barbiturates have been shown to enhance the GABA-mediated depression of mitral cell excitability (in the rabbit) that follows an antidromic mitral cell action potential induced by stimulation of its axon in the lateral olfactory tract (see Nicoll, 1980). Changes in olfactory perception do not seem to have been observed with barbiturates or benzodiazepines in man, which may mean that ongoing GABAergic inhibition is almost maximal so that any slight enhancement induced by the benzodiazepines would be difficult to observe.

\section{Cerebral cortex}

The cerebral cortex, another brain region rich in benzodiazepine and $\mathrm{GABA}_{\mathrm{A}}$ receptors, contained an intense, finely granular im- mune reaction; cell profiles and processes could not be resolved. From radiohistochemical studies, benzodiazepine (and $\mathrm{GABA}_{\mathrm{A}}$ ) receptors are known to be concentrated in particular laminae of rat brain (IV > I, VI $\gg$ II, III, V) and of human calcarine cortex (III, IVA, IVC) (Young and Kuhar, 1979b, 1980; Richards and Möhler, 1984; Richards et al., 1986c). Receptor antigenic sites were concentrated in laminae II, III, IV, and VI; in other words, they were more homogenously distributed than would be expected from radiohistochemical observations. Among GABAergic cortical neurons, aspinous and sparsely spinous stellate cells in the visual cortex branch profusely in lamina IV (Ribak, 1978), where the GABA concentration is reported to be highest (Ishikawa et al., 1983); all stellate neurons are apparently inhibitory.

Inhibition of cortical pyramidal neurons is mediated by GABA (see Haefely and Polc, 1986). Ribak (1985) has recently observed that inhibitory GABAergic nerve terminals of chandelier cells, for example, in monkey sensorimotor cortex decrease at sites of focal epilepsy.

\section{Pallidal regions}

The islands of Calleja, ventral pallidum, and globus pallidus were intensely and discretely immunoreactive, corresponding to the dense GABAergic innervation of large dendrites and occasional neurons in these areas. Fallon et al. (1983) have described symmetrical synapses that encircle smooth pallidumtype dendrites of larger cells in the islands of Calleja. In marked contrast to these regions was the very fine immune reaction in the caudate putamen and nucleus accumbens, which correlates well with the intensity of GAD immunoreactivity in these areas (Ribak et al., 1979; Mugnaini and Oertel, 1985). The receptor antigenic sites on isolated neurons and their varicose processes in the white matter of the anterior commissures and internal capsule fibers were unexpected. Presumably because of the sparse distribution of these neurons, neither GAD nor benzodiazepine binding sites have previously been reported to occur in these regions; the synaptic connections of these neurons are not known.

\section{Hippocampal formation}

The distribution of receptor antigenic sites in the hippocampus and dentate gyrus is consistent with a high density of receptors on pyramidal and granule cell dendrites (finely granular immune reaction), as well as on isolated neurons and their processes in the oriens layer and in the hilus of the hippocampus and dentate gyrus, respectively. The comparatively low density on pyramidal and granule cell perikarya, despite electron microscopic evidence for GABAergic nerve terminals on these cells (Somogyi et al., 1983; Mugnaini and Oertel, 1985), suggests either receptor heterogeneity or the sensitivity of the method is insufficient to detect such a density (at least at the light microscopic level). Radiolabeled benzodiazepine receptors have been found in the oriens, radiatum, and lacunosum moleculare layers of the hippocampus and in the molecular layer of the dentate gyrus (Young and Kuhar, 1980; Richards and Möhler, 1984; Richards et al., 1986c); the density is much lower in the pyramidal and granule cell layers. No receptors occur in the fimbria and alveolus, and a moderate to low density occurs in the subiculum. The consistently lower density of receptor antigenic sites in the CA3 region of the hippocampus compared with the CAl region reveals possible differences in the GABAergic innervation of pyramidal cell dendrites (and their sensitivity to benzodiazepines?) 
in these regions. The identity of the immunoreactive cells and their processes in the oriens layer and hilus is not known.

Benzodiazepines enhance recurrent inhibition in the hippocampus (see Alger and Nicoll, 1982; Haefely and Polc, 1986). Their marked effects in this brain region point to a significant contribution to the anticonvulsant and anxiolytic activity and perhaps to the induction of anterograde amnesia. Recently, Peterson and Ribak (1986) have described morphological evidence for increased inhibition of basket cells in the dentate gyrus of seizure-sensitive mongolian gerbils; whether the receptor immunoreactive cell profiles in the hilus of rat and bovine and postmortem human dentate gyrus are indeed basket cell ncurons is currently being investigated by double-labeling with GAD and receptor antibodies.

\section{Thalamus}

In the thalamus, the presence of a high density of receptor antigenic sites in some regions (rostral dorso- and ventrolateral nuclei) is consistent with the property of benzodiazepines to prevent the spread of seizures from this brain area. Electrophysiological studies focusing on their GABA-potentiating action in the thalamus are lacking.

\section{Hypothalamus}

The hypothalamic nuclei, including those related to feeding behavior (lateral and ventromedial nuclei) (Kelly and Grossman, 1980; Morley et al., 1984), were moderate to poorly but evenly stained. GAD is also reported to be evenly distributed in the hypothalamus (Mugnaini and Oertel, 1985). Surprisingly, the median eminence, which is known to have a dense GABAergic innervation, was virtually devoid of receptor antigenic sites. GABA is probably released into the portal system to reach receptors on pituitary cells.

The effects of benzodiazepines in reducing several behavioral, autonomic, and endocrine responses to emotional stimuli may be due in part to their action on GABAergic synapses in the hypothalamus. The regulation of feeding behavior by the lateral and ventromedial hypothalamus is indirectly under the control of GABAergic inhibition; benzodiazepines are known to stimulate feeding behavior (food intake).

\section{Amygdala}

In the amygdala, the basolateral nucleus has been found to contain a high density of benzodiazepine receptors in rat and human brain (Niehoff and Kuhar, 1983; Niehoff and Whitehouse, 1983) and, indeed, the lateral nucleus contained the most receptor antigenic sites.

The lateral and basolateral nuclei have been implicated in the anticonflict effect of benzodiazepines mediated by specific benzodiazepine receptors (Petersen et al., 1985). Diazepam depresses the spontaneous firing of neurons in the amygdala (Chou and Wang, 1977), which is probably mediated by GABAergic interneurons.

\section{Substantia nigra}

The substantia nigra, reticular area, contains a high density of benzodiazepine receptors, most of which are on dendrites, some on neurons. Major GABAergic projections to this area derive from the striatum and globus pallidus (Fonnum et al., 1978; Nagy et al., 1978; Ribak et al., 1980; Araki et al., 1985); there is also evidence for a nigrothalamic GABAergic pathway (Straughan et al., 1980). A considerable part of the dendritic region of A9 dopaminergic neurons of the substantia nigra compacta extends into the reticular area, where they synapse with GABAergic nerve terminals (Van den Pol et al., 1985). Up to $50 \%$ of all nerve terminals in the substantia nigra are GAD positive (on cell bodies and dendrites) (Ribak et al., 1976, 1980; Berod et al., 1984). In both rat and human brain, the reticular part of the substantia nigra contained numerous receptor-immunoreactive large dendritic profiles and the occasional cell body profile.

Benzodiazepines enhance GABAergic inhibition of both dopaminergic and GABAergic output neurons (see Mereu and Biggio, 1983). The depression of the excitability of nigral reticular (dopaminergic?) neurons by GABAergic mechanisms may be relevant to the anticonvulsant activity of benzodiazepines.

\section{Colliculi}

Benzodiazepine receptor antigenic sites were highly concentrated in the superficial superior colliculus (layers I-III) and throughout the inferior colliculi; these brain areas are associated with visual and auditory pathways, respectively. The dorsal nucleus of the lateral lemniscus, a precollicular nucleus whose majority of neurons are GAD positive and which is a major GABAergic feed-forward inhibitory center in the auditory pathway (Adams and Mugnaini, 1984), also had a high density of receptor-immunoreactive sites.

\section{Cerebellum}

In the cerebellum, the distribution of receptor antigenic sites is compatible with their localization on Purkinje cell dendrites and on isolated (stellate or basket?) cell bodies in the molecular layer, as well as in glomeruli and on granule cells in the granule cell layer. Purkinje cells, Golgi, basket, and stellate cells are known to be GABAergic. Golgi and Purkinje cells are GAD positive. In the granule cell layer, Golgi nerve terminals form a circle of GAD-positive nerve terminals on granule cell dendritcs (Saito et al., 1974). Nerve terminals on dendritic trunks (more than spines) of Purkinje cells, basket cells, and stellate cells are also GAD positive. The unexpectedly high density of immunoreactive sites in the granular, as compared with the molecular, layer [correlating with the distribution of high-affinity GABA (muscimol) and TBPS binding sites, but not with that of radiolabeled benzodiazepine receptors and low-affinity GABA (bicuculline) binding sites] (Palacios et al., 1981; Wamsley et al., 1985), might be due to the fact that with our monoclonal antibody we are visualizing both high- and low-affinity conformational states of $\mathrm{GABA}_{\mathrm{A}}$ receptors in the cerebellum (and other regions of the $\mathrm{CNS}$ ). The exceptionally high density of high-affinity $\mathrm{GABA}_{\mathrm{A}}$ receptors in the granular layer of the cerebellum, which might contain low-affinity benzodiazepine binding sites, produces the apparent discrepancy. A structural difference between receptors in cerebellum and other brain regions was recently described (Sweetnam and Tallman, 1986). Recently, Fry et al. (1985) demonstrated that, in Lurcher mutant mice (deficient in Purkinje cells and the majority of granule cells), ${ }^{3} \mathrm{H}$-muscimol binding was $25 \%$ of control littermates, although ${ }^{3} \mathrm{H}$-flunitrazepam binding was unchanged; these findings are difficult to reconcile with ours.

One of the major functions of the cerebellum is the control of muscle tone and coordination. Benzodiazepines enhance synaptic inhibition of Purkinje cells by stellate and basket cells. It is therefore tempting to associate the muscle relaxant (antispastic), as well as the ataxic, effects of benzodiazepines with GABAergic synapses in the cerebellum. 
In deep cerebellar nuclei and lateral vestibular nucleus, receptor antigenic sites were found around large (Deiter?) neurons. The deep cerebellar nuclei and vestibular nuclei are important sites for the depressant actions of benzodiazepines on the crossed extensor reflex (Kawasaki et al., 1984). Secondary vestibular neurons receive postsynaptic inhibition from the GABAergic Purkinje cells in the cerebellar cortex, and there is evidence for an intrinsic GABAergic innervation (Houser et al., 1984). The circuit is involved in modulating various vestibular reflexes that mediate equilibrium and eye movements. A depression of the excitability of secondary vestibular neurons by enhancement of the GABAergic input from the cerebellar cortex may explain a beneficial effect of benzodiazepines on some forms of vertigo; it may also contribute to the ataxia produced by higher doses of these drugs (see Haefely and Polc, 1986).

\section{Medulla}

The high density of receptors in the reticular formation is compatible with the muscle-relaxant properties of the benzodiazepines. Muscle tone is thought to be controlled in part through polysynaptic reflexes in the reticular formation, as well as through cerebellar Purkinje cell activity.

\section{Spinal cord}

In the spinal cord, the distribution of receptor antigenic sites, similar to that of radiolabclcd receptors (Young and Kuhar, 1980; Richards and Möhler, 1984; Faull and Villiger, 1986; Richards et al., 1986c), is compatible with the presence of receptors in high density in the substantia gelatinosa (layers II, III) and layers IV and X, as well as on isolated cells and processes in layers VI-VIII. In other words, they are present in the terminal fields of primary afferent axons in the dorsal horn and around the central canal where GAD-positive terminals are concentrated (McLaughlin et al., 1975). Since some GABAergic nerve terminals are reported to be presynaptic to primary afferent terminals (Barber et al., 1978), the subcellular distribution of receptor antigenic sites in the spinal cord is currently being investigated after capsaicin administration or unilateral rhizotomy. The identity of the immunoreactive cells and processes in layers VI-VIII is not known. They are tentatively identified as small- to medium-size motor neurons and their large dendrites (sec McLaughlin et al., 1975). Peripheral-type binding sites in the spinal cord are more evenly distributed (Villiger, 1984; Richards et al., 1986c).

Primary efferent depolarization is probably mediated by GABA (see Haefely and Polc, 1986). Benzodiazepines increase the amplitude and/or duration of dorsal root potentials and accentuate and prolong the presynaptic inhibition of monosynaptic reflex responses. The influence of benzodiazepines on synaptic transmission and sensorimotor effects of these drugs on transmission in sensory pathways projecting towards the brain has been extensively investigated. A clear antinociceptive activity of benzodiazepines has not been described.

\section{Retina}

The vertebrate retina, an extracranial derivative of ectoderm that arises from an outpouching of the diencephalon during early embryogenesis, contains a localized concentration of centraltype benzodiazepine receptors (Howells et al., 1979; Paul et al., 1980; Brecha, 1983). The distribution of receptor antigenic sites is consistent with the presence of receptors on a subpopulation of amacrine cells (and some ganglion cells) and their dense ar- borizations in 3 main bands in the inner plexiform layer.

Benzodiazepine binding in the retina shows all the characteristics of brain receptors (ligand specificity, GABA modulation). Horizontal cells and a subpopulation of amacrine cells are GABAergic (Brandon et al., 1979; Vaughn et al., 1981; Wu et al., 1981; Schnitzer and Rusoff, 1984; Brandon, 1985). GAD activity is present in 4 distinct bands in the inner plexiform layer and in displaced amacrine cells. Amacrine cell processes arborize within selected laminae of the inner plexiform layer and synapse with amacrine, ganglion, and bipolar cells. As far as could be determined in double-labeling experiments and in adjacent sections, the receptor-immunoreactive bands in the inner plexiform layer of the rat retina were present in GADpositive bands, although the latter were rather wider and perhaps more diffuse (see Fig. 9C). This finding suggests that, in the rat retina, all benzodiazepine receptors are associated with GABAergic nerve terminals. Ultrastructural studies are requircd to confirm this finding.

The functional role of GABAergic synapses in the transmission between photoreceptors and bipolar and ganglion cells is still unknown; GABA is reported to mediate inhibition of ganglion cells in the cat retina (Ikeda and Sheardown, 1983; Bolz et al., 1985). Benzodiazepines attenuate the light-induced increase in dopamine turnover in a subpopulation of amacrine cells (Kamp and Morgan, 1982). In retinae of 25-d-old darkadapted rats, a $30-40 \%$ increase in benzodiazepine binding was observed (Biggio et al., 1981; Rothe et al., 1985). Furthermore, a $25 \%$ decrease in binding occurred in the open eyes of rats with monocular deprivation. Whether therapeutic doses of benzodiazepines affect retinal function is not yet known. Although retinal GABAergic mechanisms might be involved in visual symptoms reported during benzodiazepine withdrawal, changes in visual perception do not seem to have becn obscrved during benzodiazepine therapy in man. No overt effects on electroretinograms have been observed in studies on rabbits (Laurent, unpublished observations), although subtle effects cannot be excluded.

\section{Pineal}

In accordance with the lack of radiolabeled benzodiazepine receptors in rat pineal was the absence of receptor antigenic sites in this part of the epithalamus. A GABAergic innervation and GABA receptors are also lacking. Since neuronal-type benzodiazepine receptors are reported to be present in human pineal (Lowenstein et al., 1985), species differences obviously occur. A high density of non-neuronal binding sites occurs in rat pineal (Richards and Möhler, 1984; Richards et al., 1986c); they probably mediate the benzodiazepine-induced potentiation of norepinephrine stimulation of mclatonin synthesis (Mathew et al., 1984).

\section{Pituitary}

All parts of the pituitary, the anterior and neurointermediate lobes, lacked immunoreactivity, upon light microscopic examination. Preliminary electron microscopic findings, however, indicate that receptor antigenic sites are indeed present on anterior pituitary cells and in axosomatic synapses of the intermediate lobe. The identity of these cells is not yet known. Compatible with the presence of GABA receptors in the anterior lobe is the recent finding that a low density of central-type benzodiazepine binding sites (beyond the limits of immunohistochemical detection with the light microscope?) can be demonstrated radiohistochemically in this part of the pituitary and 
in the intermediate lobe (Brown and Martin, 1984). This finding has been confirmed using a ${ }^{125}$ I-labeled benzodiazepine receptor ligand (Richards and Séquier, unpublished observations).

Only the neurointermediate lobe contains GABAergic nerve terminals (Oertel et al., 1982). The anterior lobe is not innervated but is regulated by hypothalamic release-regulating factors (including GABA?) via the portal vessels (Racagni et al., 1982). Peripheral-type (glial?) binding sites are highly concentrated in the neural lobes (presumably on pituicytes) (De Souza et al., 1985; Richards et al., 1986c).

The release of melatonin-stimulating hormone is reported to be stimulated by exogenous GABA (Tomiko et al., 1983); accordingly, rat melanotrophs appear to possess GABA receptors (Taraskevich and Douglas, 1985). Thus, these findings, as well as the reported presence of GABA receptors (Anderson and Mitchell, 1983) and GABA-related chloride channels (Anderson et al., 1985) in the anterior lobe and the benzodiazepine enhancement of muscimol-stimulated prolactin release (Anderson and Mitchell, 1983, 1984; Schettini et al., 1984), are compatible with the presence of a small number of $\mathrm{GABA}_{\mathrm{A}}$ and benzodiazepine receptors in the anterior and intermediate lobes.

\section{Peripheral tissues}

Receptor antigenic sites could not be detected in the tissues investigated (sympathetic ganglia, adrenals, kidneys). Despite increasing evidence for the presence of GABA (perhaps as a neurotransmitter) in certain peripheral tissues (see Erdö, 1985), their GABA receptors are not usually coupled to benzodiazepine receptors.

However, although sympathetic ganglion cells (e.g., in superior cervical ganglia) are not innervated by GABAergic nerve terminals, the cells have GABA receptors and respond to GABA mimetics with a bicuculline-sensitive depolarization (see Little, 1984). Possible receptor-mediated benzodiazepine effects have also been observed. Moreover, histochemical and biochemical studies (Kataoka et al., 1984) have revealed that bovine adrenal chromattin cells contain GABA, GAD, and GABA-I. In addition, the presence of $\mathrm{GABA}_{A}$ and benzodiazepine receptors (although not extensively characterized) has becn revcalcd biochemically by radioligand binding studies. Recently, chlorideselective, bicuculline-sensitive GABA-receptor channels were demonstrated (electrophysiologically) in adrenomedullary chromaffin cells (Bormann and Clapham, 1985); GABA-induced currents were potentiated by diazepam. The apparent discrepancy between these findings and our negative observations might be explained by a different receptor sensitivity and extremely low density in peripheral tissue sections or even by the presence of a different receptor protein.

\section{Subcellular localization of receptors}

A variety of approaches has been used to identify specific parts of cell-surface membranes as the subcellular binding sites of receptor ligands. (1) Photoaffinity ligands that become covalently (irreversibly) bound when exposed to ultraviolet light have been used to photolabel benzodiazepine receptors, e.g., with ${ }^{3} \mathrm{H}$-flunitrazepam, ${ }^{3} \mathrm{H}$-clonazepam, and ${ }^{3} \mathrm{H}$-Ro $15-4513$ (a partial inverse agonist derived from Ro 15-1788) (Möhler et al., 1980, 1981, 1984; Sieghart et al., 1987). (2) Other ligands that become irreversibly bound when crosslinked with glutaraldehyde fixative have been described by Hamel and Beaudet (1984a, b) for the localization of opioid receptors.
However, radiohistochemical studies at an ultrastructural level still suffer from the same limitations in resolution of the autoradiographic approach, namely, radiation scatter, diffusion, and nonspecific binding of the radioligand. Thus, using ${ }^{3} \mathrm{H}$-flunitrazcpam as a photoaffinity label, we were able to determine the probability of benzodiazepine receptors occurring in regions of synaptic contacts (Möhler et al., 1980), some of which were GABAergic (Möhler et al., 1981). However, the receptors could not be attributed to specific neuronal membranes.

Receptor localization by immunocytochemistry overcomes the limitations in resolution of the radiohistochemical technique. As previously mentioned, receptors for dopamine, glycine, and $\mathrm{ACh}$ (nicotinic) have been visualized by nondiffusible markers such as peroxidase-coupled or colloidal gold-coupled secondary antibodies (Lentz and Chester, 1977; Goldsmith et al., 1979; Nghiêm et al., 1983; Sealock et al., 1984; Triller et al., 1985).

In the present study we have visualized the subcellular distribution of benzodiazepine receptors in rat substantia nigra and globus pallidus. Receptor antigenic sites were confined to preand postsynaptic membranes of axodendritic and axosomatic contacts. This finding is in line with previous observations by Lo et al. (1983) that benzodiazepine receptor ligands might modulate not only a postsynaptic $\mathrm{GABA}_{\mathrm{A}}$ receptor complex (Trifiletti and Snyder, 1985), but also a presynaptic GABA receptor, presumably GABA autoreceptors (Mitchell and Martin, 1978; Kuriyama et al., 1984; Lockerbie and Gordon-Weeks, 1985; Tietz et al., 1985). However, since diffusion of the enzyme (PAP) reaction product from the post- to the presynaptic membrane might conceivably occur (see Landis, 1985), the presynaptic localization will have to be confirmed (e.g., by the use of a goldlabeled secondary antibody as marker and by in situ hybridization). New views on the mechanism of action of benzodiazepine receptor ligands would open up should this finding also hold true for other regions of the CNS.

In conclusion, the present findings on the cellular and subcellular distribution of receptor antigenic sites in the mammalian CNS, reveal the precise target sites for the actions of benzodiazepines in the CNS. In the near future we hope to identify the transmitter(s) of these target cells in double-labeling experiments using, for example, GAD; tyrosine hydroxylase, and 5-hydroxy tryptamine antibodies with our receptor monoclonal antibody. In this way, we hope to determine (electron microscopically) whether all benzodiazepine receptors are associatcd with GABAergic synapses. Investigations are also in progress to study the receptor antigenic sites in human brain biopsies and postmortem tissue of patients with, for example, epilepsy or chronic anxiety. Such studies might reveal pathological changes in the receptor that could underlie such CNS disease states (see Whitehouse, 1985; Chugani and Olsen, 1986). Finally, cDNA and cRNA probes will soon become available for the identification of those target cells expressing the receptor (in situ hybridization studies). This approach could also be used to demonstrate whether the receptor is regulated at the level of the genome, for example, in cases of acute or chronic drug tolerance.

\section{Appendix}

Abbreviations used in the figures:

$A$

aca anterior commissure

Ach accumbens nucleus 


$\begin{array}{ll}C A 1 & \text { field CA1 of } \Lambda \text { mmon's horn } \\ C A 3 & \text { feld CA3 of Ammon's horn } \\ c b & \text { cerebellum } \\ C C & \text { corpus callosum } \\ C P u & \text { caudate putamen } \\ d & \text { dendrite } \\ D G & \text { dentate gyrus } \\ E P l & \text { external plexiform layer, olfactory bulb } \\ F r & \text { frontal cortex } \\ G C L & \text { ganglion cell layer, retina } \\ G l & \text { glomerular layer, olfactory bulb } \\ G P & \text { globus pallidus } \\ G r D G & \text { granular layer, dentate gyrus } \\ h i & \text { hippocampus } \\ H i l & \text { hilus dentate gyrus } \\ i C & \text { internal capsule } \\ I C & \text { inferior colliculus } \\ I G r & \text { internal granular layer, olfactory bulb } \\ I N L & \text { inner nuclear layer, retina } \\ I P L & \text { inner plexiform layer, retina } \\ L a & \text { lateral amygdaloid nucleus } \\ I m & \text { lacunosum molecular layer, hippocampus } \\ M & \text { medulla } \\ M i & \text { mitral cell layer of bulb } \\ M o l & \text { molecular layer, dentate gyrus } \\ m o t & \text { motor neuron } \\ m y & \text { myelin } \\ n t & \text { nerve terminal } \\ O B & \text { olfactory bulb } \\ O N i & \text { nerve layer, olfactory bulb } \\ O N L & \text { outer nuclear layer } \\ O P L & \text { outer plexiform layer } \\ O r & \text { oriens layer, hippocampus } \\ P & \text { pons } \\ P C & \text { Purkinje cell layer, cerebellum } \\ P P & \text { perforant pathway } \\ P M g r & \text { granular layer, cerebellum } \\ P M m o & \text { molecular layer, cerebellum } \\ P R & \text { photoreceptive layer } \\ P y & \text { pyramidal ccll laycr, hippocampus } \\ R a d & \text { stratum radiatum layer, hippocampus } \\ S P & \text { synapse } \\ I-X & \text { subiculum } \\ & \text { substantia nigra, reticular } \\ \text { thalamus } \\ \text { vextral pallidum } \\ \text { R } & \end{array}$

\section{References}

Adams, J. C., and E. Mugnaini (1984) Dorsal nucleus of the lateral lemniscus: A nucleus of GABAergic projection of neurons. Brain Res. Bull. 13: 585-590.

Alger, B. E., and R. A. Nicoll (1982) Feed-forward dendritic inhibition in rat hippocampal pyramidal cells studied in vitro. J. Physiol. (Lond.) 328: 105-123.

Anderson, R. A., and R. Mitchell (1983) Multiple benzodiazepine binding sites in rat pituitary. Br. J. Pharmacol. 79: 290P.

Anderson, R. A., and R. Mitchell (1984) Benzodiazepines potentiate the effect of muscimol on prolactin secretion in vitro. Br. J. Pharmacol. 82: 343P.

Anderson, R. A., R. H. McAllister-Williams, and R. Mitchell (1985) GABA-related anion channels, labelled by $\left[{ }^{35} \mathrm{~S}\right] \mathrm{t}-$ butylbicyclophos- phorothionate ([${ }^{35}$ S]TBPS), in rat pituitary. J. Physiol. (Lond.) 362 : 43P.

Araki, M., P. L. McGeer, and E. G. McGeer (1985) Striatonigral and pallidonigral pathways studied by a combination of retrogradc horseradish peroxidase tracing and a pharmacohistochemical method for $\gamma$-aminobutyric acid transaminase. Brain Res. 331: 17-24.

Barber, R., and K. Saito (1976) Light microscopic visualization of GAD and GABA-T in immunocytochemical preparations of rodent CNS. In GABA in Nervous System Function, E. Roberts, T. N. Chase, and D. B. Tower, eds, pp. 113-132, Raven, New York.

Barber, R. P., J. E. Vaughn, K. Saito, B. J. McLaughlin, and E. Roberts (1978) GABAergic terminals are presynaptic to primary afferent terminals in the substantia gelatinosa of the rat spinal cord. Brain Res. 141: 35-55.

Berod, A., M. Chat, L. Paut, and M. Tappaz (1984) Catecholaminergic and GABAergic anatomical relationship in the rat substantia nigra, locus coeruleus and hypothalamic median eminence. J. Histochem. Cytochem. 32: 1331-1338.

Biggio, G., P. Guarneri, and M. G. Corda (1981) Benzodiazepine and GABA receptors in the rat retina: Effect of light and dark adaptation. Brain Res. 216: 210-214.

Bolz, J., T. Frumkes, T. Voigt, and H. Wässle (1985) Action and localization of $\gamma$-aminobutyric acid in the cat retina. J. Physiol. (Lond.) 362: 369-393.

Bormann, J., and D. E. Clapham (1985) $\gamma$-Aminobutyric acid receptor channels in adrenal chromaffin cells: A patch-clamp study. Proc. Natl. Acad. Sci. USA 82: 2168-2172.

Bowery, N. G., G. W. Price, A. L. Hudson, D. R. Hill, G. P. Wilkin, and M. J. Turnbull (1984) GABA receptor multiplicity. Visualization of different receptor types in the mammalian CNS. Neuropharmacology 23: 219-231.

Brandon, C. (1985) Retinal GABA neurons: Localization in vertcbratc species using an antiserum to rabbit brain glutamate decarboxylase. Brain Res. 344: 286-295.

Brandon, C., D. M. K. Lam, and J. Y. Wu (1979) The $\gamma$-aminobutyric acid system in rabbit retina: Localization by immunocytochemistry and autoradiography. Proc. Natl. Acad. Sci. USA 76: 3557-3561.

Brecha, N. (1983) Retinal neurotransmitters: Histochemical and biochemical studies. In Chemical Neuroanatomy, P. C. Emson, ed., pp. 85-129, Raven, New York.

Brown, C., and I. L. Martin (1984) Autoradiographic localization of benzodiazepine receptors in the rat pituitary gland. Eur. J. Pharmacol. 102: 563-564.

Chou, D. T., and S. C. Wang (1977) Unit activity of amygdala and hippocampal neurons: Effects of morphine and benzodiazepines. Brain Res. 126: 427-440.

Chugani, H. T., and R. W. Olsen (1986) Benzodiazepine/GABA receptor binding in vitro and in vivo in analysis of clinical disorders. In Benzodiazepine/GABA Receptors and Chloride Channels: Structure and Functional Properties, R. W. Olsen and J. C. Venter, eds., pp. 315-335, Liss, New York.

Ciliax, B. J., J. B. Penney, and A. B. Young (1986) In vivo ${ }^{3} \mathrm{H}-f l u-$ nitrazepam binding: Imaging of receptor regulation. J. Pharmacol. Exp. Ther. 238: 749-757.

De Souza, E. B., R. R. H. Anholt, K. M. M. Murphy, S. H. Snyder, and M. J. Kuhar (1985) Peripheral-type benzodiazepine receptors in endocrine organs: Autoradiographic localization in rat pituitary, adrenal, and testis. Endocrinology 116: 567-573.

Emson, P. C., and S. P. Hunt (1981) Anatomical chemistry of the cerebral cortex. In The Organization of the Cerebral Cortex (Neurosci. Res. Prog.), pp. 325-345.

Erdö, S. L. (1985) Peripheral GABAergic mechanisms. Trends Pharmacol. Sci. 6: 205-208.

Fagg, G. E., and A. C. Foster (1983) Amino acid neurotransmitters and their pathways in the mammalian central nervous system. Neuroscience 9: 701-719.

Fallon, J. H., S. E. Loughlin, and C. E. Ribak (1983) The islands of Calleja complex of rat basal forcbrain. III. Histochemical evidence for a striatopallidal system. J. Comp. Neurol. 218: 91-120.

Faull, R. L. M., and J. W. Villiger (1986) Benzodiazepine receptors in the human spinal cord: A detailed anatomical and pharmacological study. Neuroscience 17: 791-802.

Fonnum, F., Z. Gottesfeld, and I. Grofovà (1978) Distribution of glutamate decarboxylase, choline acetyltransferase and aromatic amino acid decarboxylase in the basal ganglia of normal and operated 
rats. Evidence for striatopallidal, striatoentopeduncular, and striatonigral GABAergic fibers. Brain Res. 143: 125-138.

Fry, J. P., C. Rickets, and T. J. Biscoe (1985) On the location of $\gamma$-amino-butyrate and benzodiazepine receptors in the cerebellum of the normal $\mathrm{C} 3 \mathrm{H}$ and Lurcher mutant mouse. Neuroscience 14:10911101 .

Goeders, N. E., and M. J. Kuhar (1985) Benzodiazepine receptor binding in vivo with [ $\left.{ }^{3} \mathrm{H}\right] \mathrm{Ro}$ 15-1788. Life Sci. 37: 345-355.

Goldsmith, P. C., M. T. Cronin, and R. I. Weiner (1979) Dopaminereceptor sites in the anterior pituitary. J. Histochem. Cytochem. 27: $1205-1207$.

Haefely, W. E., and P. Polc (1986) Physiology of GABA enhancement by benzodiazepines and barbiturates. In Benzodiazepine-GABA Receptors and Chloride Channels. Structural and Functional Properites, R. W. Olsen and J. C. Venter, eds., pp. 97-133, Liss, New York.

Haefely, W. E., E. Kyburz, M. Gerecke, and H. Möhler (1985) Recent advances in the molecular pharmacology of benzodiazepine receptors and in the structure activity relationships of their agonists and antagonists. Adv. Drug Res. 14: 166-322.

Halasz, N., and G. M. Sheperd (1983) Neurochemistry of the vertebrate olfactory bulb. Neuroscience 10: 579-619.

Halasz, N., A. Ljungdahl, and T. Hökfelt (1979) Transmitter histochemistry of the rat olfactory bulb. III. Autoradiographic localization of $\mathrm{H}^{3}$-GABA. Brain Res. 167: 221-240.

Hamel, E., and A. Beaudet (1984a) Electron microscopic autoradiographic localization of opioid receptors in rat neostriatum. Nature 312: $155-157$

IIamel, E., and A. Beaudet (1984b) Localization of opioid binding sites in rat brain by electron microscopic autoradiography. J. Electron Microsc. Technol. 1: 317-329.

Häring, P., C. Stähli, P. Schoch, B. Takacs, T. Staehelin, and H. Möhler (1985) Monoclonal antibodies reveal structural homogeneity of GA$\mathrm{BA}_{\mathrm{A}} /$ benzodiazepine receptors in different brain areas. Proc. Natl. Acad. Sci. USA 82: 4837-4841.

Houser, C. R., R. P. Barber, and J. E. Vaughn (1984) Immunocytochemical localization of glutamic acid decarboxylase in the dorsal lateral vestibular nucleus: Evidence for an intrinsic and extrinsic GABAergic innervation. Neurosci. Lett. 47: 213-220.

Howells, R. D., J. M. Hiller, and E. J. Simon (1979) Benzodiazepine binding sites are present in retina. Life Sci. 25: 2131-2136.

Hunt, S. P. (1983) Cytochemistry of the spinal cord. In Chemical Neuroanatomy, P. C. Emson, ed., pp. 53-84, Raven, New York.

Ikeda, H., and J. J. Sheardown (1983) Transmitters mediating inhibition of ganglion cells in the cat retina: Ionotophoretic study in vivo. Neuroscience 8: 837-853.

Ishikawa, K., S. Watabe, and N. Goto (1983) Laminal distribution of $\gamma$-aminobutyric acid (GABA) in the occipital cortex of rats: Evidence as a neurotransmitter. Brain Res. 277: 361-364.

Jaffé, E. H., and A. C. Cuello (1980) Release of $\gamma$-aminobutyrate from the external plexiform layer of the rat olfactory bulb: Possible dendritic involvement. Neuroscience 5: 1859-1869.

Jaffé, E. H., and A. C. Cuello (1981) Neuronal and glial release of $\left[{ }^{3} \mathrm{H}\right]-\mathrm{GABA}$ from the rat olfactory bulb. J. Neurochem. 37: 14571466.

Jaffé, E. H., A. C. Cuello, and J. V. Priestley (1983) Localization of ${ }^{3}$ II-GABA in the rat olfactory bulb: An in vivo and in vitro autoradiographic study. Exp. Brain Res. 50: 100-106.

Jones, E. G. (1983) The thalamus. In Chemical Neuroanatomy, P. C. Emson, ed., pp. 257-293, Raven, New York.

Kamp, C. W., and W. W. Morgan (1982) Benzodiazepines suppress the light response of retinal dopaminergic neurons in vivo. Eur. $J$. Pharmacol. 27: 343-346.

Kataoka, Y., Y. Gutman, A. Guidotti, P. Panula, J. Wroblewski, D. Cosenza-Murphy, J. Y. Wu, and E. Costa (1984) Intrinsic GABAergic system of adrenal chromaffin cells. Proc. Natl. Acad. Sci USA 81: 3218-3222.

Kawasaki, K., A. Matsushita, M. Satoh, and H. Takagi (1984) The lateral vestibular nucleus is a very important site for the depressant actions of benzodiazepines on the crossed extensor reflex. Neurosci. Lett. Suppl. 17: S61.

Kelly, J., and S. P. Grossman (1980) GABA and hypothalamic feeding systems. Brain Res. Bull. 5: 237-244.

Kuhar, M. J., E. B. De Souza, and J. R. Unnerstall (1986) Neurotransmitter receptor mapping by autoradiography and other methods. Annu. Rev. Neurosci. 9: 27-59.
Kuriyama, K., K. Kanmori, J. Taguchi, and Y. Yoneda (1984) Stressinduced enhancement of suppression of ${ }^{3} \mathrm{H}-\mathrm{GABA}$ release from striatal slices by presynaptic autoreceptor. J. Neurochem. 42: 943-950.

Landis, D. M. D. (1985) Promise and pitfalls in immunocytochemistry. Trends Neurosci. 8: 312-317.

Lentz, T. L., and J. Chester (1977) Localization of acetylcholine receptors in central synapses. J. Cell Biol. 75: 258-267.

Little, H. J. (1984) The effects of benzodiazepine agonists, inverse agonists and Ro 15-1788 on the responses of the superior cervical ganglion to GABA in vitro. Br. J. Pharmacol. 83: 57-68.

Lo, M. M. S., D. L. Niehoff, M. J. Kuhar, and S. H. Snyder (1983) Differential localization of type I and type II benzodiazepine binding sites in substantia nigra. Nature 306: 57-60.

Lockerbie, R. O., and P. R. Gordon-Weeks (1985) $\gamma$-Aminobutyric $\operatorname{acid}_{\mathrm{A}}\left(\mathrm{GABA}_{\mathrm{A}}\right)$ receptors modulate $\left[{ }^{3} \mathrm{H}\right] \mathrm{GABA}$ release from isolated neuronal growth cones in the rat. Neurosci. Lett. 55: 273-277.

Lorente de Nó, R (1934) Studies on the structure of the cerebral cortex. II. Continuation of the study of the ammonic system. J. Psychol. Neurol. 46: 113-177.

Lowenstein, R. P., R. Rosenstein, E. Caputti, and P. Cardinali (1985) Benzodiazepine binding sites in human pineal gland. Eur. J. Pharmacol. 106: 399-403.

Macrides, F., and B. J. Davis (1983) The olfactory bulb. In Chemical Neuroanatomy, P. C. Emson, ed., pp. 391-426, Raven, New York.

Mathew, E., A. G. Parfitt, D. Sugden, D. L. Engelhardt, E. A. Zimmerman, and D. C. Klein (1984) Benzodiazepines: Rat pinealocyte binding sites and augmentation of norepinephrine-stimulated $\mathrm{N}$-acetyltransferase activity. J. Pharmacol. Exp. Ther. 228: 434-437.

McLaughlin, B. J., R. Barber, K. Saito, and E. Roberts (1975) Immunocytochemical localization of glutamate decarboxylase in rat spinal cord. J. Comp. Neurol. 164: 305-322.

Mereu, G., and G. Biggio (1983) Effect of agonists, inverse agonists and antagonists of benzodiazepine receptors on the firing rate of substantia nigra pars reticulata neurons. In Benzodiazepine Recognition Site Ligands: Biochemistry and Pharmacology, G. Biggio and E. Costa, eds., pp. 201-209, Raven, New York.

Mitchell, P. R., and I. L. Martin (1978) Is GABA release modulated by presynaptic receptors? Nature 274: 904-905.

Möhler, H., and T. Okada (1977) Benzodiazepine receptors: Demonstration in the central nervous system. Science 198: 849-851.

Möhler, H., M. K. Battersby, and J. G. Richards (1980) Benzodiazepine receptor protein identified and visualized in brain tissue by a photoaffinity label. Proc. Natl. Acad. Sci. USA 77: 1666-1670.

Möhler, H., J. G. Richards, and J. Y. Wu (1981) Autoradiographic localization of benzodiazepine receptors in immunocytochemically identified $\gamma$-aminobutyrergic synapses. Proc. Natl. Acad. Sci. USA 78: 1935-1938.

Möhler, H., W. Sieghart, J. G. Richards, and W. Hunkeler (1984) Photoaffinity labeling of benzodiazepine receptors with a partial inverse agonist. Eur. J. Pharmacol. 102: 191-192.

Möhler, H., P. Schoch, J. G. Richards, P. Häring, B. Takacs, and C. Stähli (1986) Monoclonal antibodies: Probes for structure and location of the GABA receptor/benzodiazepine receptor/chloride channel complex. In Benzodiazepine/GABA Receptors and Chloride Channels: Structural and Functional Properties, R. W. Olsen and J. C. Venter, eds., pp. 285-297, Liss, New York.

Molander, C., Q. Xu, and G. Grant (1984) The cytoarchitectonic organization of the spinal cord in the rat. I. The lower thoracic and lumbosacral cord. J. Comp. Neurol. 230: 133-141.

Morley, J. E., B. A. Gosnell, and A. S. Levine (1984) The role of peptides in feeding. Trends Pharmacol. Sci. 5: 468-471.

Mugnaini, E., and W. H. Oertel (1985) An atlas of the distribution of GABAergic neurons and terminals in the rat CNS as revealed by GAD immunohistochemistry. In Handbook of Chemical Neuroanatomy, Vol. 4: GABA and Neuropeptides in the CNS, Pt. 1, A. Björklund and T. Hökfelt, eds., pp. 436-595, Elsevier, Amsterdam.

Nagy, J., D. Carter, and H. Fibiger (1978) Anterior striatal projections to the globus pallidus, entopeduncular nucleus and substantia nigra in the rat: The GABA connection. Brain Res. 158: 15-29.

Nghiêm, Ho., J. Cartaud, C. Dubreuil, C. Kordeli, G. Buttin, and J. P. Changeux (1983) Production and characterization of a monoclonal antibody directed against the 43,000-dalton $\mathrm{v}$, polypeptide from Torpedo marmorata electric organ. Proc. Natl. Acad. Sci. USA 80: 64036407.

Nicoll, R. A. (1971) Pharmacological evidence for GABA as the trans- 
mitter in granule cell inhibition in the olfactory bulb. J. Neurophysiol. 46: 639-648.

Nicoll, R. A. (1980) Sedative-hypnotics: Animal pharmacology. In Handbook of Psychopharmacology, L. K. Iversen, S. D. Iversen, and S. H. Snyder, eds., pp. 187-234, Raven, New York.

Niehoff, D. L., and M. J. Kuhar (1983) Benzodiazepine receptors: Localization in rat amygdala. J. Neurosci. 3: 2091-2097.

Niehoff, D. L., and P. J. Whitehouse (1983) Multiple benzodiazepine receptors: Autoradiographic localization in normal human amygdala Brain Res. 276: 237-245.

Oertel, W. H., E. Mugnaini, M. L. Tappaz, V. K. Weise, A. L. Dahl, D. E. Schmechel, and I. J. Kopin (1982) Central GABAergic innervation of neurointermediate pituitary lobe: Biochemical and immunocytochemical study in the rat. Proc. Natl. Acad. Sci. USA 79 675-679.

Ottersen, O. P., and J. Storm-Mathisen (1984) Neurons containing or accumulating transmitter amino acids. In Handbook of Chemical Neuroanatomy, Vol. 3: Classical Transmitters and Transmitter Receptors in the CNS, Pt. II, A. Björklund, T. Hökfelt, and M. J. Kuhar, eds., pp. 141-246. Elsevier, Amsterdam.

Palacios, J. M., J. K. Wamsley, and M. J. Kuhar (1981) High-affinity GABA receptors: Autoradiographic localization. Brain Res. 222: 285307.

Palay, S. L., and V. Chan-Palay (1974) Cerebellar Cortex: Cytology and Organization, Springer, Berlin.

Parnavelas, J. G., and J. K. McDonald (1983) The cerebral cortex. In Chemical Neuroanatomy, P. C. Emson, ed., pp. 505-549, Raven, New York.

Paul, S. M., M. Zatz, and P. Skolnick (1980) Demonstration of brainspecific benzodiazepine receptors in rat retina. Brain Res. 187: 232246.

Paxinos, G., and C. Watson (1982) The Rat Brain in Stereotaxic Coordinates, Academic, Sydney.

Petersen, E. N., C. Braestrup, and J. Scheel-Krüger (1985) Evidence that the anticonflict effect of midazolam in amygdala is mediated by the specific benzodiazepine receptors. Neurosci. Lett. 53: 285-288.

Peterson, G. M., and C. E. Ribak (1986) Morphological evidence for increased inhibition of basket cells in the dentate gyrus of Mongolian gerbils. Soc. Neurosci. Abstr. 11: 1321.

Racagni, G., J. A. Apud, D. Cocchi, V. Locatelli, and E. E. Muller (1982) Minireview: GABAergic control of anterior pituitary hormone secretion. Life Sci. 31: 823-838.

Ribak, C. E. (1978) Aspinous and sparsely-spinous stellate neurons in the visual cortex of rats contain glutamic acid decarboxylase. J. Neurocytol. 7: 461-478

Ribak, C. E. (1985) Axon terminals of GABAergic chandelier cells are lost at epileptic foci. Brain Res. 326: 251-260.

Ribak, C. E., J. E. Vaughn, K. Saito, R. Barber, and E. Roberts (1976) Immunocytochemical localization of glutamate decarboxylase in rat substantia nigra. Brain Res. 116: 287-298.

Ribak, C. E., J. E. Vaughn, K. Saito, R. Barber, and E. Roberts (1977) Glutamate decarboxylase localization in neurons of the olfactory bulb. Brain Res. 126: 1-18.

Ribak, C. E., J. E. Vaughn, and E. Robcrts (1979) The GABA neurons and their axon terminals in rat corpus striatum demonstrated by GAD immunocytochemistry. J. Comp. Neurol. 187: 261-284.

Ribak, C. E., J. E. Vaughn, and E. Roberts (1980) GABAergic nerve terminals decrease in the substantia nigra following hemitransections of the striatonigral and pallidonigral pathways. Brain Res. 192:413420.

Richards, J. G., and H. Möhler (1984) Benzodiazepine receptors. Neuropharmacology 23: 233-242.

Richards, J. G., and H. Möhler (1985) Recent advances in the visualization and quantification of benzodiazepine receptors. In Proceedings of the Wenner-Gren Center International Symposium on Quantitative Neuroanatomy in Transmitter Research, L. F. Agnati and K. Fuxe, eds., pp. 407-415, MacMillan, London

Richards, J. G., H. Möhler, and W. Haefely (1982) Benzodiazepinc binding sites: Receptors or acceptors? Trends Pharmacol. Sci. 3: 233235.

Richards, J. G., H. Möhler, P. Schoch, P. Häring, B. Takacs, and Ch. Stähli (1984) The visualization of neuronal benzodiazepine receptors in the brain by autoradiography and immunohistochemistry. $\mathrm{J}$. Receptor Res. 4: 657-669.

Richards, J. G., H. Möhler, and W. Haefely (1986a) Mapping ben- zodiazepine receptors in the CNS by radiohistochemistry and immunohistochemistry. In Neurology and Neurobiology, Vol. 16: Neurohistochemistry, Modern Methods and Applications, P. Panula, H. Päivärinta, and S. Soinila, eds., pp. 629-677, Liss, New York.

Richards, J. G., P. Schoch, H. Möhler, and W. Haefely (1986b) Benzodiazepine receptors resolved. Experientia 42: 121-126.

Richards, J. G., H. Möhler, and W. Haefely (1986c) Benzodiazepine receptors and their ligands. In Mechanisms of Drug Action, G. N. Woodruff, ed., pp. 131-176, Macmillan, New York.

Roberts, E. (1986) GABA: The road to neurotransmitter status. In Benzodiazepine/GABA Receptors and Chloride Channels: Structural and Functional Propertics, R. W. Olsen and J. C. Venter, eds., pp. 139, Liss, New York.

Rothe, T., R. Schliebs, and V. Bigl (1985) Benzodiazepine receptors in the visual structures of monocularly deprived rats. Effect of light and dark adaptation. Brain Res. 329: 143-150.

Saito, K., R. Barber, J. Y. Wu, T. Matsuda, E. Roberts, and J. E. Vaughn (1974) Immunohistochemical localization of glutamic acid decarboxylase in rat cerebellum. Proc. Natl. Acad. Sci. USA 71: 269-273.

Schettini, G., M. J. Cronin, S. B. O'Dell, and R. M. MacLeod (1984) The benzodiazepine agonist diazepam inhibits basal and secretagogue-stimulated prolactin release in vitro. Brain Res. 291: 343-349.

Schlumpf M. J. G. Richards, W. J ichtensteiger, and H. Möhler (1983) An autoradiographic study of the prenatal development of benzodiazepine-binding sites in rat brain. J. Neurosci. 3: 1478-1487.

Schnitzer, J., and $\Lambda$. C. Rusoff (1984) Horizontal cells of the mouse retina contain glutamic acid decarboxylase-like immunoreactivity during early developmental stages. J. Neurosci. 4: 2948-2955.

Schoch, P., P. Häring, B. Takacs, C. Stähli, and H. Möhler (1984) A GABA/benzodiazepine receptor complex from bovine brain: Purification, reconstitution and immunological characterization. J. Receptor Res. 4: 189-200.

Schoch, P., J. G. Richards, P. Häring, B. Takacs, C. Stähli, T. Staehelin, W. Haefely, and H. Möhler (1985) Co-localization of GABA receptors and benzodiazepine receptors in the brain shown by monoclonal antibodies. Nature 314: 168-171.

Schulman, J. A. (1983) Chemical neuroanatomy of the cerebral cortex In Chemical Neuroanatomy, P. C. Emson, ed., pp. 209-228, Raven, New York.

Schwerdtfeger, W. K. (1984) Structure and Fiber Connections of the Hippocampus, pp. 1-74, Springer, Berlin.

Sealock, R., E. W. Barnaby, and S. C. Froehner (1984) Ultrastructural localization of the Mr 43,000 protein and the acetylcholine recepto in Torpedo postsynaptic membranes using monoclonal antibodies. $\mathbf{J}$ Cell Biol. 98: 2239-2244.

Shepherd, G. M. (1972) Synaptic organization of the mammalian olfactory bulb. Physiol. Rev. 52: 864-917.

Shiosaka, S., S. Masahiro, S. Inagaki, E. Senba, Y. Hara, K. Takasuki, H. Takagi, Y. Kawai, and M. Tohyama (1983) Putative neurotransmitters in the amygdaloid complex with special reference to peptidergic pathways. In Chemical Neuroanatomy, P. C. Emson, ed., pp. 359-389, Raven, New York.

Sieghart, W., A. Eichinger, J. G. Richards, and H. Möhler (1987) Photoaffinity labeling of benzodiazepine receptor proteins with the partial inverse agonist $\left[{ }^{3} \mathrm{H}\right] \mathrm{Ro}$ 15-4513: A biochemical and autoradiographic study. J. Neurochem. 48: 46-52.

Silverman, A. J., and G. E. Pickard (1983) The hypothalamus. In Chemical Neuroanatomy, P. C. Emson, ed., pp. 295-336, Raven, New York.

Somogyi, P., A. D. Smith, M. G. Nunzi, A. Gorio, H. Takagi, and J. Y. Wu (1983) Glutamate decarboxylase immunoreactivity in the hippocampus of the cat: Distribution of immunoreactive synaptic terminals with special reference to the axon initial segment of pyramidal neurons. J. Neurosci. 3: 1450-1468.

Somogyi, P., A. J. Hodgson, I. W. Chubb, B. Penke, and A. Erdei (1985) Antisera to $\gamma$-aminobutyric acid. II. Immunocytochemical application to the central nervous system. J. Histochem. Cytochem. 32:240248.

Squires, R. F., and C. Braestrup (1977) Benzodiazepine receptors in rat brain. Nature $266: 732-734$.

Sternberger, L. A. (1979) Immunocytochemistry, 2nd ed., Wiley, New York.

Storm-Mathisen, J. (1978) Localization of putative transmitters in the hippocampal formation with a note on the connections to septum 
and hypothalamus. In Functions of the Septo-Hippocampal System [Ciba Found. Symp. (new series) 58: 49-86].

Straughan, D. W., N. K. Macleod, T. A. Jamcs, and I. C. Kilpatrick (1980) GABA and the nigrothalamic pathway. Brain Res. Bull. 5: $7-11$.

Sweetnam, P. M., and Tallman, J. F. (1986) Regional difference in brain benzodiazepine receptor carbohydrates. Mol. Pharmacol. 29. 299-306.

Taraskevich, P. S., and W. W. Douglas (1985) Pharmacological and ionic features of $\gamma$-aminobutyric acid receptors influencing electrical properties of melanotrophs isolated from the rat pars intermedia. Neuroscience 14: 301-308.

Teyler, T. J., and P. Discenna (1984) The topological anatomy of the hippocampus: A clue to its function. Brain Res. Bull. 12: 711-719.

Tietz, E. I., T. H. Chiu, and H. C. Rosenberg (1985) Pre- versus postsynaptic localization of benzodiazepine and $\beta$-carboline binding sites. J. Neurochem. 44: 1524-1534.

Tomiko, S. A., P. S. Taraskevich, and W. W. Douglas (1983) GABA acts directly on cells of pituitary pars intermedia to alter hormone output. Nature 301: 706-707.

Trifiletti, R. R., and S. H. Snyder (1985) Localization of type I benzodiazepine receptors to postsynaptic densities in bovine brain. $\mathrm{J}$. Neurosci. 5: 1049-1057.

Triller, A., F. Cluzeaud, F. Pfeiffer, H. Betz, and H. Korn (1985) Distribution of glycine receptors at central synapses: An immunoelectron microscopy study. J. Cell Biol. 101: 683-688.

Van den Pol, A., A. D. Smith, and J. F. Powell (1985) GABA axons in synaptic contact with dopamine neurons in the substantia nigra: Double immunocytochemistry with biotin-peroxidase and protein $\mathrm{A}-$ colloidal gold. Brain Res. 348: 146-154.

Vaughn, J. E., E. V. Famiglietti, R. P. Barber, K. Saito, E. Roberts, and C. E. Ribak (1981) GABAergic amacrine cells in rat retina: Im- munocytochemical identification and synaptic connectivity. J. Comp. Neurol. 197: 113-127.

Villiger, J. W. (1984) Specific ${ }^{3} \mathrm{H}-\mathrm{Ro} 5-4864$ binding to rat spinal cord membranes: Evidence for peripheral type benzodiazepine recognition sites. Neurosci. Lett. 46: 267-270.

Walaas, I. (1983) The hippocampus. In Chemical Neuroanatomy, P. C. Emson, ed., pp. 337-358, Raven, New York.

Wamsley, J., K., and J. M. Palacios (1984) Amino acid and benzodiazepine receptors. In Handbook of Chemical Neuroanatomy, Vol. 3: Classical Transmitters and Transmitter Receptors in the CNS, Pt. II, A. Björklund, T. Hökfelt, and M. J. Kuhar, eds., pp. 352-385, Elsevier, Amsterdam.

Wamsley, J. K., D. R. Gehlert, and R. W. Olsen (1986) The benzodiazepine, barbiturate-sensitive convulsant GABA receptor, chloride ionophore complex: Autoradiographic localization of individual components. In Benzodiazepine/GABA Receptors and Chloride Channels. Structural and Functional Properties, R. W. Olsen and J. C. Venter, eds., pp. 299-313, Liss, New York.

Whitehouse, P. J. (1985) Receptor autoradiography: Applications in neuropathology. Trends Neurosci. 8: 434-437.

Wu, J. Y., C. Brandon, Y. Y. T. Su, and D. M. K. Lam (1981) Immunocytochemical and autoradiographic localization of GABA system in the vertebrate retina. Mol. Cell Biochem. 39: 229-238.

Young, W. S. III, and M. J. Kuhar (1979a) A new method for receptor autoradiography: $\left[{ }^{3} \mathrm{H}\right]$ opioid receptors in rat brain. Brain Res. 179 . 255-270.

Young, W. S. III, and M. J. Kuhar (1979b) Autoradiographic localization of benzodiazepine receptors in the brains of humans and animals. Nature 280: 393-395.

Young, W. S. III, and M. J. Kuhar (1980) Radiohistochemical localization of benzodiazepine receptors in rat brain. J. Pharmacol. Exp. Ther. 212: 337-346. 